\title{
The botanical legacy of Martinus Houttuyn (1720-1798) in Geneva
}

\author{
Dirk Onno Wijnands ${ }^{\dagger}$, Johannes Heniger, Jan Frederik Veldkamp, Nicolas Fumeaux \& \\ Martin W. Callmander
}

In memory of Dr. Dirk Onno Wijnands (1945-1993) (see also De Jong, 1993)

\begin{abstract}
WIJNANDS, D.O. ${ }^{\dagger}$, J. HENIGER, J.F. VELDKAMP, N. FUMEAUX \& M.W. CALLMANDER (2017). The botanical legacy of Martinus Houttuyn (1720-1798) in Geneva. Candollea 72: 155-198. In English, English abstract. DOI: http://dx.doi.org/10.15553/c2017v721a11

The contribution made by Martinus Houttuyn (1720-1798) to systematic botany has been widely underestimated. Fourteen volumes of the second part of his Natuurlijke Historie of Uitvoerige Beschrijving der Dieren, Planten en Mineraalen, published between 1773 and 1783, dealt with botany. Houttuyn popularized the Linnaean system and published more than 150 species and several genera. The historical context of this early botanical work is described. The history of the acquisition of Houttuyn's herbarium is outlined and an English translation of his auction catalogue is provided. We discuss Houttuyn's exotic herbaria from the Cape of Good Hope (South Africa), Ceylon (Sri Lanka), Java (Indonesia), and Japan. Houttuyn did not go abroad to collect plants. His herbarium consisted of material from many collectors, with the vast majority of specimens collected by Thunberg, but collections were also made by Auge, Radermacher, Richter, and possibly von Wurmb, while material from unknown collectors is also present. The main set of Houttuyn herbarium, which proves to be present in the Geneva herbarium, was originally part of the Burman herbarium bought by Delessert in 1801 on the advice of Augustin-Pyramus de Candolle. It is now incorporated in the Pre-Linnaean herbarium (G-PREL). Much smaller sets from Java are present in Leiden (L) and Amsterdam (AMD, now in L). In many cases Houttuyn described new species on the basis of Thunberg specimens before Linnaeus f. or Thunberg did, whose identical but later names are based on the specimens in their own herbaria, and although some might consider these to be homonyms, we regard them as isonyms because their types are duplicates of the same gatherings. A selection of 111 names are discussed, most of which were published by Houttuyn in the Natuurlijke Historie. Others are linked to Burman, Thunberg, Linnaeus f. or A.-P. de Candolle. A total of 57 lectotypes and one epitype are designated.
\end{abstract}

\section{Keywords}

Houttuyn - Thunberg - Burman - Linnaeus f. - A.-P. de Candolle - Ceylon - Indonesia - Japan Java - South Africa - Sri Lanka - Nomenclature - Botanical History

Addresses of the authors:

JH: Milosdreef 27, 3562 VE, Utrecht, The Netherlands.

JFV : Naturalis Biodiversity Center, Herbarium, POB 9517, 2300 RA, Leiden, The Netherlands. E-mail : jef.veldkamp@naturalis.nl

NF, MWC: Conservatoire et Jardin botaniques de la Ville de Genève, C.P. 60, 1292 Chambésy, Switzerland. E-mail: martin.callmander@ville-ge.ch 


\section{Introduction}

Martinus Willem Houttuyn (born March 26, 1720 in Hoorn - buried May 2,1798, Amsterdam; often erroneously cited as "Maarten", a given name he never used himself) was a Dutch naturalist who published the Natuurlijke Historie of Uitvoerige Beschrijving der Dieren, Planten en Mineraalen [Natuurlijke Historie] (Houttuyn, 1761-1785), a work in 3 parts and 37 volumes containing over 21,500 pages of text in Dutch. The second part (Houttuyn, 1773-1783a) deals with plants and is distantly related to ed. 12 and 13 of Linnaeus's Systema naturae (1766-1768) and Systema vegetabilium (1774). A generic index to this part, Systematische bladwijzer der planten (Houttuyn, 1785), was issued in the last volume of part 3 : it follows Murray's ed. 14 of Systema vegetabilium (1784) and includes later described genera, "sometimes amended and improved".

Martinus was the son of Willem Maartensz Houttuyn (1692-1756), medical doctor in Hoorn, and Aagje Zeylemaker (1719-?). Frans Houttuyn (?-1765), a publisher in Hoorn and later in Amsterdam, is often but erroneously mentioned as the father, perhaps because he published the Uitgezogte Verbandelingen (1757-1765) to which Martinus contributed a considerable part. In fact he was a cousin. Martinus studied medicine in Leiden, graduating in 1749. After a short period as a physician in Hoorn, he settled in Amsterdam, although it is not clear whether he actually had a medical practice there. His main occupation appears to have been natural history, and he owned a large cabinet of naturalia that was auctioned in 1787 and 1789 (see Appendix I). He seems to have been a likable and very modest person. Many of his contributions and the first volumes of the Natuurlijke Historie were published without an author, and no portrait of him is known.

Houttuyn's contribution to systematic botany, apart from his popularization of the Linnaean system, has been widely underestimated, even though for the Phanerogams alone he described eleven new genera and proposed at least 140 new species or combinations (see MerRILL, 1938). This neglect is no doubt due to the fact that his work was written in Dutch and also because it was extremely expensive for the time : the fourteen botanical volumes alone already cost fl. 77 (Dutch guilders) and 12 stuivers (shillings: 20 to a guilder) at publication. The cost of the complete set was fl. 188/15 (Arrenberg, 1788: 372). For comparison, a physician at that time had an average income of around fl. 500 a year. A Dutch master painting could be had for about fl. 20! Jan Andries Auge (1711-1796), Gardener of the Company's Garden in the Cape from 1755 until 1778 (Wijnands, 1992: 490) was paid fl. 14 a month. In November 2016, complete sets were offered online for prices ranging between $€ 7,500$ and 10,860.

A title issue of the Natuurlijke Historie printed on better paper and with exquisitely hand-coloured plates was published more or less simultaneously with the Handleiding tot de plant-en kruidkunde (Houttuyn, 1773-1783b). Stafleu \& Cowan (1979: 344) mentioned the presence of copies in BR and K, noting that the Natuurlijke Historie has coloured plates. This is incorrect: copies at herbaria such as A, BR, HH, $\mathrm{L}, \mathrm{NY}$, and $\mathrm{U}$ are uncoloured, although another copy in $\mathrm{L}$ is coloured. The books were already expensive enough : coloured copies would have cost even more! Arrenberg (1788) did not mention these.

The Systematische bladwijzer der planten (HoutTuyn, 1785) is a critically updated listing of genera, with diagnoses, based on Murray's ed. 14 (1784) of Systema vegetabilium.

Houttuyn's work was probably best known from the German treatment (not a literal translation!) by ChristmanN \& Panzer (1777-1788). This was cited by e.g. Willdenow (1797) and apparently used by the early compilers of Index Kewensis. The original set, which cost fl. 72, was offered online in November 2016 for a price ranging from $€ 1,700$ to 2,000. There is an earlier German treatment of the zoological part by MüLler (1773-1776) that is not mentioned by Boeseman \& De Ligny (2004: 122). The latter also noted on page 26 that Yokusai Iinuma (1783-1865) consulted it for his 20 volume iconography of Japanese plants (IINUMA, 1874). He presumably could read Dutch, as that was, up to the middle of the 19th century, the only Western language allowed in Japan.

As was usual for works like these, the first volume published paid for the next one, and so on. Apparently they came in loose quires and the buyer was then free to have them bound as he pleased (or could afford). As an aid to the binder, the bundles were provided with an unpaged pamphlet, the Aanwyzingen der plaaten [Aanwyz. Plaat.] (Directives to the binder on where to insert the plates). Having served their purpose, these may have been discarded after binding and so may be absent in some copies, or, when present, may have been bound in various (unexpected) places and are thus easily overlooked. The logical placement seems to be between the table of contents and the main text. The Aanwyz. Plaat. are of importance as in some cases they contained new Latin names or combinations published by Houttuyn that are not found in the main text, e.g. Celosia japonica Houtt. (see below under $n^{\circ} 26$ ) or Truellum japonicum Houtt. (see below under $n^{\circ} 109$ ).

As an aside, to give honour where it is due and too often neglected: the copper plates used for Natuurlijke Historie were engraved first by Jan Caspar Philips (c. 1700-1775) and then from part 6 onwards by his pupil and nephew Caspar Philips (1732-1789).

Merrill $(1938,1939)$ provided a study of Houttuyn's botanical publications, while Boeseman \& DE LignY (2004) published an extensive analysis of the genealogy of his family, the history of the Natuurlijke Historie and other publications, and the origin and fate of the zoological naturalia in his possession. 


\section{Houttuyn's herbarium}

\section{The search for Houttuyn's herbarium}

An obvious place to look for Houttuyn specimens was $G$, as LAsègue $(1845: 66)$ reported that they were bought by Benjamin Delessert (1773-1847) as part of the Burman herbarium. Delessert bought the latter herbarium in 1801 (Morren, 1843: 129) on the advice of Augustin-Pyramus de Candolle (1778-1841), who heard about it during a trip to Holland in 1799 (see Candolle, 2004). Candolle (1801), in a letter to his mother, explained how pleased he was with this purchase: "Delessert vient de faire l'acquisition d'un herbier magnifique qui a appartenu à un ancien botaniste." ["Delessert just purchased a wonderful herbarium which belonged to an earlier botanist."] Six hundred duplicates of this herbarium were given to de Candolle, who incorporated them in his herbarium the same year (CANDOLLE, 1830a), mentioning: “... plantes de l'herbier de Burman... doubles de plantes du Cap" [“... plants from the Burman herbarium... duplicates of plants from the Cape..."]. His son, Alphonse de Candolle (1806-1893), mentioned 602 species in La Phytographie (CAndolle, 1880: 401). More recently, Burdet (2008: X) explained that Houttuyn's specimens present in the de Candolle herbarium are much more numerous. They clearly did not originate only from the Cape. This would explain the absence of some specimens in the Burman herbarium (see Cineraria incisa Thunb. ex Houtt. below under $\mathrm{n}^{\circ} 28$ ). The first author's search for Houttuyn specimens, while searching for a specimen of Athanasia L. in G-DC (based on IDC microfiche 800), resulted, for example, in the discovery of four sheets from Asia: Ochna nitida sensu DC. [non O. nitida Sw.] from Ceylon [2 sheets]; Oldenlandia brachypoda DC. from Java; and Piper officinarum C. DC. from Java, thus confirming the presence of Houttuyn material from these areas.

A closer look at the material of Athanasia revealed a specimen of $A$. tomentosa Thunb., labelled as $A$. pubescens (L.) L. and annotated in Houttuyn's characteristic handwriting (see Fig. 1-11). The Linnaean binomial, the Linnaean classification, and a reference to Commelin (1701: 93, tab. 47) are given. The same information is present in Houttuyn (Nat. Hist. II(6) : 39. 1776). However, as he did not cite a specimen, he must have received it afterwards. Another Houttuyn specimen in $\mathrm{G}$ was mentioned by Hilliard \& Burtt (1981: 239), who recognised it as the type of Gnaphalium aureum Thunb. ex Houtt. (see below under $n^{\circ}$ 50). DAHLgRen (1968: 70) identified the type specimen in $\mathrm{G}$ as the basis for Houttuyn's figure of Aspalathus pedunculata Houtt. (see below under $\mathrm{n}^{\circ} 18$ ).

It is remarkable that MERRILL (1938) failed to locate any of Houttuyn's specimens in G. Perhaps he did not recognise Houttuyn's very characteristic handwriting? (see Agrostis javanica Houtt. below under $\mathrm{n}^{\circ} 3$ for an exemple, which was seen by Merrill but not recognised for what it was).
Candolle (1801) referred to the Burman herbarium as a single unit. The explanation offered by WiJNANDs (1992: 492) of the possible accidental merging of the Burman and Houttuyn herbaria when they arrived in Geneva, "[Houttuyn collections]... were erroneously stamped as Herbier Burman", is very plausible. Starting in 1992, the Burman herbarium (Burman and Houttuyn herbaria) in $\mathrm{G}$ was extracted from the general herbarium (Wijnands, 1992; Staples \& JaCQUEMoud, 2005) although several specimens remain in the general herbarium $(\mathrm{G})$. Some Houttuyn specimens are also part of the de Candolle (G-DC) historical herbarium. The Burman herbarium has recently received a specific acronym (G-PREL) and will be referred to below as the Pre-Linnaean collection. In the process, many more Houttuyn specimens were discovered. However, it is not yet possible to provide a comprehensive account of them: much research remains to be done. Only a selection of specimens is discussed below, illustrating the kind of issues one may expect in consulting the herbarium and the publications based on it.

From our research, it is clear that the main set of specimens from Houttuyn's herbarium is now incorporated in the PreLinnaean collection (G-PREL). It is currently impossible to know exactly how many sheets are there; only time will tell. Other Houttuyn specimens have been found in $\mathrm{L}$ (with a total of 70 including seven originally in AMD) and $\mathrm{P}$ (mainly Solanaceae, unreturned loans?), and currently one in C (Vahl herbarium).

\section{Characteristics of Houttuyn specimens}

Sheets originating from various Houttuyn herbaria have been recognised on the basis of his handwriting (Fig. 1-11), as pictured by van Steenis \& VELdKamp (1973), and of a letter dated 1762 from Houttuyn to Linnaeus (Houttuyn, 1762). On several sheets, 18 th century Dutch watermarks are present, which support the supposition that most of Houttuyn's exsiccata have not been remounted afterwards. The most frequent Dutch watermark is the French lily without a coat of arms or other additions, e.g. the specimens of Amaryllis dubia Houtt. [non A. dubia L.], Galega villosa L., Mussaenda frondosa L., and Tragia involucrata L. The same watermark, but on a coat of arms, is present on sheets of Plumbago rosea L., Rajania quinata Thunb. ex Houtt., and R. quinquefolia L. Various watermarks of the Dutch paper maker Jan Honig \& Sons at Zaandijk figure on the sheets of Achyranthes lanata L., Apocynum frutescens L., Nerium zeylanicum L., and Ocimum sanctum $\mathrm{L}$. This paper is known to have been produced from 1737 to 1787 (Churchill, 1967: 15).

The watermark "D. \& C. Blauw" is present on sheets of Athanasia pubescens, Ixia campanulata Houtt., and I. uniflora L. Dirk Blauw \& Co. was a Dutch mill active from 1733 to 1827 (Churchill, 1967: 13). The watermark of the Dutch United East India Company (VOC: Vereenigde Oost-Indische 
Compagnie [United East Indian Company]), Chamber of Amsterdam, consisting of the intertwisted letters $\mathrm{A}, \mathrm{V}, \mathrm{O}$, and C, figures on the sheet of Sida cordifolia L. A countermark "IV" (Jean Villedary) is found on Agrostis javanica Houtt.

Occasionally specimens on Houttuyn's sheets are mounted in an ornamental printed pot, a curious custom of the mid18th century in the Netherlands and Flanders, e.g. by Johannes Burman (1706-1779) and his son Nicolaas Laurens Burman (1734-1793), George Clifford (1685-1760), David de Gorter (1717-1783), and Adriaan van Royen (1704-1779) (WiJnands \& Heniger, 1991: 137, tab. 5 ; Wijnands, 1992: 491, tab. 1). The same urns were also used by Daniel de la Roche (17431813) (Wijnands, 1992: 492), the Belgian E.-J. D'Oignies (1735-1791; 4 vol., c. 1780, L), and the Bernese Albrecht von Haller (1708-1777) (depicted by Burdet, 1975 : 383). Houttuyn was one of the last botanists to use these.

A simple pot printed in blue was found in $\mathrm{L}$ : a specimen of Caesalpinia pulcherrima (L.) Sw. (Fig. 1), but more elaborate designs were used, as in Plumeria acuminata Ait. (Fig. 2).

The Houttuyn sheets in G differ in their state of originality. The characteristics of an original, undamaged Houttuyn sheet are a top and a bottom line (Fig. 3). On the left side of the top line he noted the origin of the plant such as Planta Capensis, Planta Ind. Orient. Javanica, Planta Japonica, and Planta Zeylanica; also Planta Ind. Orient. occurs, which could refer to either Java or Ceylon, with an example from the Moluccas (see Myristica fragrans Houtt. below under $\mathrm{n}^{\circ}$ 64). On the right side of the top line is the relevant Linnaean class. On the left of the bottom line, Houttuyn wrote the plant name in Linnaean binomial nomenclature, sometimes followed by a citation from the Natuurlijke Historie and more rarely by some diagnostic notes (Fig. 4). For binomials coined by himself, he frequently added "mihi", just as he did in the Natuurlijke Historie (Fig. 4). Some sheets have a number written near the statement of origin, which appear to be consecutive, e.g. in Geranium L. from the Cape 145, 146, 147, 148, 149. No number is higher than the total number of specimens quoted for the respective herbaria in the auction catalogue. From the sheets found in $\mathrm{G}$ it is clear that Houttuyn generally based his discussions in the Natuurlijke Historie on extensive herbarium material, and conversely, he referred newly received specimens to his published treatments. Unfortunately, several original sheets have been trimmed. Nevertheless, some of them are almost completely preserved, with Houttuyn's top and bottom lines. From others, however, his annotations have been cut off and pasted or pinned on the sheet (Fig. 4, 5, 8-11).

\section{The provenance of Houttuyn's specimens}

The history of Houttuyn's acquisitions is complex (see BoEsEMAN \& De Ligny, 2004). This is partly due to the absence of correspondence to him, and partly to the fact that he did not always clearly state the origin of his specimens. Based on the auction catalogue (HouttuYn, 1789a, often filed sub J. Posthumus \& P. Posthumus, 1789, see Appendix I) and on his remarks in the Natuurlijke Historie, the present notes deal only with his exotic herbaria from the Cape of Good Hope (South Africa), Ceylon (Sri Lanka), Japan, and Java (Indonesia).

Houttuyn never went abroad to collect plants. His herbarium thus consisted of material from many collectors. In the botanical section, "Deel"II, of the Natuurlijke Historie, Houttuyn frequently referred to exsiccata of exotic species in his possession and he occasionally established new genera and species based on them. Some other new species were based on living plants in the Botanical Gardens of Amsterdam [Burmans] and Leiden [A. van Royen and his nephew David van Royen (1727-1799)] along with material from his own collection.

Of importance here is Carl Peter Thunberg (1743-1828) who, as Supreme Chirurgeon [Opperchirurgijn] of the Dutch VOC (1772-1777), provided Houttuyn with many specimens from the Cape, Ceylon [Sri Lanka], Java (often with a mention of Batavia for Jakarta), and Japan, and will be mentioned numerous times below (WIJNANDs, 1987).

Many sheets in $\mathrm{G}$ and some in $\mathrm{L}$ were annotated by Thunberg. His calligraphic writing of generic names (Fig. 5,11) is identical to that seen in his letters of $1771-1775$ to Linnaeus (Thunberg, 1771-1775), and to that in his herbarium (UPSTHUNB). According to Sмiтн (1793), Houttuyn was one of Thunberg's sponsors and thus directly or indirectly received specimens from his travels to the Cape, Ceylon, Java, and Japan. These specimens in his herbarium are therefore most likely duplicates of material in Thunberg's herbarium (UPSTHUNB, and also in at least H, M, or S). A few of Thunberg's Japanese specimens in G were not found in UPS-THUNB : e.g. Polygala japonica Houtt. (see below under $n^{\circ} 84$ ), and Rumex japonicus Houtt. (see below under $\mathrm{n}^{\circ} 98$ ).

JuEL (1918) made no mention of Houttuyn with respect to Thunberg collections, and GunN \& CoDD (1981) overlooked him as the owner of a Cape herbarium.

In L, three specimens were annotated by David van Royen: Mussaenda fruticosa L. (L-908.204-226) "Op Java rondom Samarang”, e.g. a Thunberg collection; Myristica fragrans (L-908.133-1797) "Pro Myristica vera dedit Cl. Houttn. 1784" and "Myristica officinalis s. vera. Linn. Suppl. 265. Cl. Houttuin dedit Jun. 1784"; and Piper longum L. (L-908.165-114) "Piper longum L. Cl. Houttuin dedit Jun 1784".

\section{The Cape of Good Hope herbarium}

Houttuyn described his Cape herbarium in the auction catalogue sub D (see Appendix I), but he did not mention a collector. The first reference to a Cape specimen (see Protea linearis Houtt. below under $n^{\circ}$ 91) is discussed in Houtruyn's Natuurlijke Historie II (1773-1783), vol. 4: 116 published in 1775 [cited below as Nat. Hist. II(4) : 116. 1775]. In a note 




Fig. 1. - Nerium oleander L. Example of a decorative pot in in Houttuyn's herbarium in L. [@ Nationaal Herbarium Nederland, Naturalis, L] 
on p. 381, he wrote: "From time to time I have bought this collection being transferred from the Cape." Under Mesembryanthemum pugioniforme L. (Nat. Hist. II(9) : 34-35, tab. 53. 1778), he noted "delivered to me by an East Indian skipper from the Cape". Throughout the Natuurlijke Historie, Houttuyn, discussing many of his Cape specimens, did not mention a collector's name. Quite likely he obtained this collection through one of those "private enterprises" that were so strictly forbidden by the VOC and so the origin had to be kept secret. Thunberg, who stayed at the Cape from 1772 until 1775, was not mentioned as the collector of this Cape herbarium. On the contrary, Thunberg was unaware of its existence until he visited Houttuyn in October 1778, when he inspected it and saw species in it that he had collected, e.g. Atractylis angustifolia Thunb. ex Houtt. and Cineraria incisa.

The Governor of the Cape at that time, Rijk Tulbagh (16991771), known for his good offices in the shipment of specimens to Linnaeus (Gunn \& CoDD, 1981: 352), is not a likely source. In the discussion on Tulbagbia L. (Nat. Hist. II(12): 127-128. 1780), Houttuyn mentioned that this genus was named after the late Mr. Tulbagh, former Governor of the Cape of Good Hope, "by whom a great number of Cape seeds, bulbs and dried plants have been delivered to Messrs. Burmannus here, for the use of the Hortus Medicus", but he did not refer to Tulbagh as the collector or intermediary of his Cape herbarium. For the present we must suppose that Houttuyn paid a private collector at the Cape, who sent him specimens. This might have been Jan Andries Auge (1711-1805), who accompanied visiting naturalists such as Thunberg, while D. van Royen called him "our ocellus botanicus [= "botanical eye", "Auge" in German] at the Cape"(Wijnands, 1992: 490). He may well have been more than that; Auge was probably the main collector of Houttuyn's Cape herbarium (Wijnands, 1990a).

\section{The Ceylon herbarium}

Houttuyn's herbarium of Ceylonese plants consisted of two parts, one collected by Thunberg (see Appendix I), the other (again ?) from an anonymous smuggler. On his way back from Japan and Java, Thunberg stayed in Ceylon from 20 August 1777 until 6 February 1778 (Thunberg, 1796, vol. 4: 205, 315), making trips to Matara and Negombo (Thunberg, 1796, vol. 4:248-282). Houttuyn apparently received his first specimens in 1783 (Nat. Hist. II(14): 43-44, tab. 94, fig. 1; see Ophioglossum zeilanicum Houtt. below under $\mathrm{n}^{\circ}$ 73). The sheets of Ochna nitida sensu DC. [non O. nitida Sw.], recognised by Houttuyn as belonging to the Linnaean class XIII Polyandria, were not discussed in his treatments of Polyandria in Nat. Hist. II(5) published in 1775 or II(9) published on 29 August 1778. Perhaps Thunberg donated Ceylon specimens during his visit in October 1778, so Houttuyn had no previous opportunity to include them.
The anonymous part of Houttuyn's Ceylon herbarium consisted of "35 Ceylonese dried plants", as mentioned in his auction catalogue sub $\mathrm{H}$. They were not necessarily gathered by a European collector. In the course of the 18th century, the Dutch government of Ceylon sent each year a selection of seeds collected by the current Surgeon of the Company to the botanical gardens in Leiden and in Amsterdam. Sometimes dried specimens were sent as well (Heniger, 1986: 77). For instance, D. van Royen, Professor in Leiden, received a Ceylonese herbarium in or shortly before 1770 , which Thunberg studied on 17 October 1770 before he left for the East (Thunberg, 1796, vol. 1: 18). In 1774 (Nat. Hist. II(2): 336), Houttuyn recorded that Burman recently had received "a collection of excellently beautiful, large dried plants of Ceylon". Apparently it arrived in Amsterdam in June 1773, together with another box with Ceylonese plant material addressed to van Royen (ARA, VOC 281, meeting of the Chamber of Amsterdam on 17 June 1773).

\section{The Japan herbarium}

According to the auction catalogue of 1789 (Houttuyn, 1789a), Houttuyn's herbarium from Japan consisted entirely of Thunberg collections. Houttuyn mentioned this herbarium first in 1779 (Nat. Hist. II(10): 368); in a note under Sonchus canadensis L., he wrote: "In the hot parts of the East and West Indies one hardly finds plants of this kind; but in Japan several ones are found, as it appears to me from the beautiful collection recently made there by the learned Mr. Thunberg and communicated to me by Mr. Radermacher, Extraordinary Councillor of India”. This remark suggests that Houttuyn did not receive this herbarium directly from Thunberg on the occasion of his visit in October 1778 (Nat. Hist. II(10): 518-519). Exidently it was Jacobus Cornelis Matheus Radermacher (1741-1783) at Batavia who received Thunberg's collections from Japan and forwarded them to Houttuyn. In a letter dated 25 January 1777 from Batavia to the Burmans, Thunberg wrote that he made herbarium collections in Japan for Radermacher as well. The question remains when Houttuyn received these specimens. From 1777, in part II(7) onwards, he described and illustrated Japanese plants from his herbarium, but without reference to Thunberg. However, in the captions to the plates of part II(8), p. (vi) in 1777, he mentioned in passing that the Japanese plants shown in plates 47 , fig. 3 and 48, fig. 1, Rumex umbellatus Houtt., and Truellum japonicum Houtt., were considered by Thunberg to belong to Polygonum chinense L., respectively P. perfoliatum Burm. f. This strongly suggests that Houttuyn had Thunberg's Japan herbarium at his disposal a year before the latter's return to Europe. This is not in conflict with the data of his journey to Japan.

Thunberg stayed in the Dutch trading post on the artificial island of Dejima (出島, Tsukishima), in the Bay of Nagasaki, from 13 August 1775 until 3 December 1776 (Thunberg, 


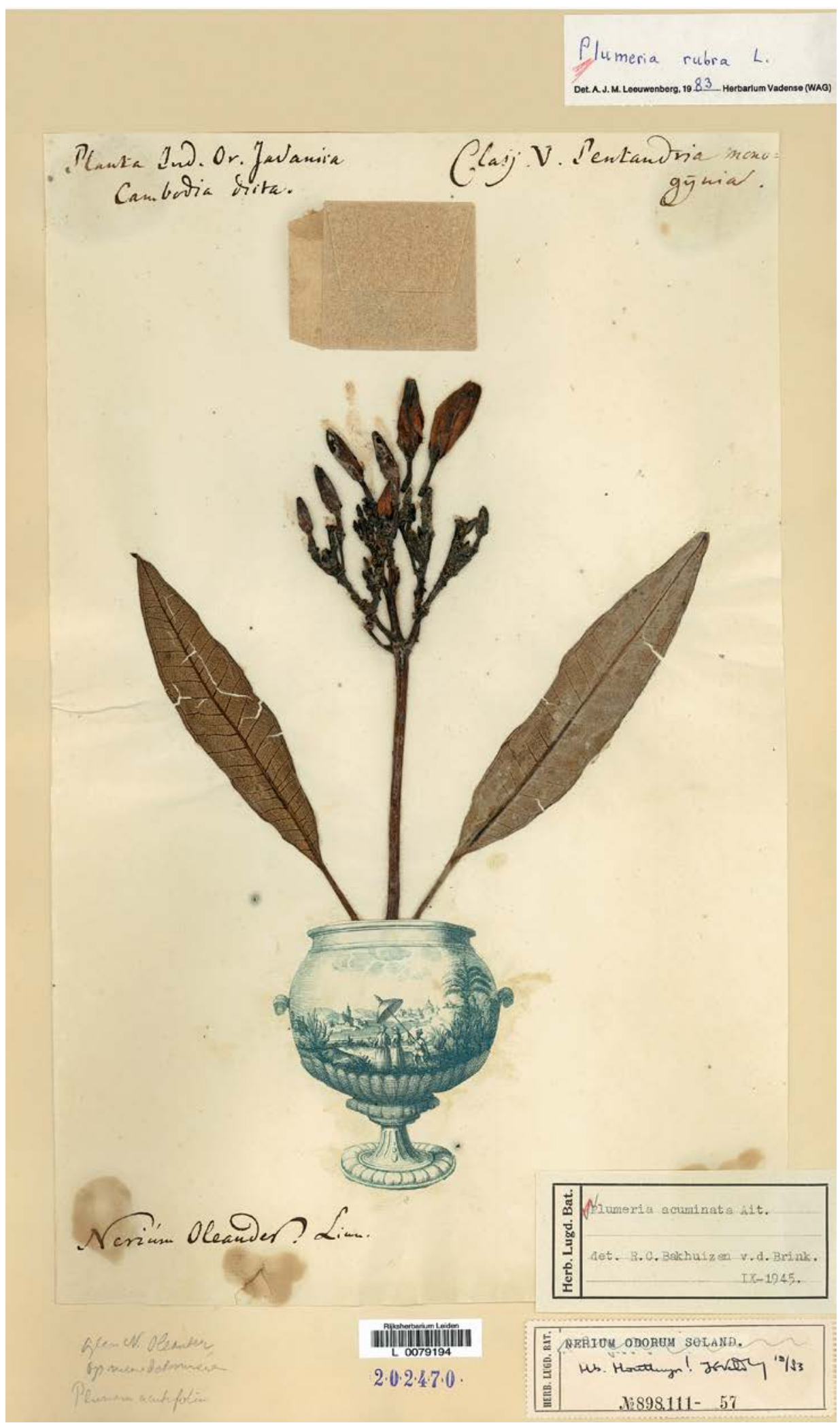

Fig. 2. - Poinciana pulcherrima L. Example of a decorative pot in Houttuyn's Java herbarium in L. [@ Nationaal Herbarium Nederland, Naturalis, L] 
1796, vol. 2 : 414 ; vol. $4: 156$ ). Initially he was confined to the island and could only study the plants in the small Company garden there. He also purchased plants from visiting Japanese interpreters. The VOC ships left for Batavia in mid-October 1775 and he sent some mounted (!) herbarium specimens with them to Burman f. in Amsterdam, as well as some seeds for the Hortus Medicus and his "patrons", i.e. Egbert de Vrij Temmink (1706-1785), Jan Deutz (1743-1784), David ten Hoven (1724-1787), and Jan van de Poll Pietersz (1726-1781) (Hall, 1830: 259-262, letter of 15.X.1775).

On 30 January 1776 Thunberg obtained permission from the Japanese governor to botanize in the vicinity of Nagasaki. A second opportunity to collect there occurred in late July 1776, when he obtained a permit for three days (ARA: Archives Dutch Factory Japan, inv. no. 186a, Journal 28.X.1775-22.XI.1776: 24 \& 96). Thunberg had to pay excessively for these permits; "By special favour of the Japanese Governor I was permitted to make several excursions around Nagasaki, when I say that for a single day, to collect plants with a big crowd of Japanese, I had to pay 16 or 18 imperiales ["rijksdaalders", rix-dollars, fl. 2.50], you certainly do not believe me, and when I say that during my stay of 15 months in Japan, I had to pay 1000 imperiales, you will even less believe me" (HaLl, 1830: 263).

The main occasion for Thunberg to collect plants was the journey of the Dutch delegation to the court at Edo (Tokyo), 4.III-29.VI.1776 (ARA : Archives Dutch Factory Japan, inv. no. 186a, Journal 28.X.1775-22.XI.1776 : 35-51; see STEARN, 1947: 108 for the route). In the spring of 1776, when Thunberg was off to Edo, a few Chinese junks left Nagasaki for Batavia. Usually the Chinese skippers would carry letters and parcels addressed to the Dutch government at Batavia. Probably Radermacher received his consignment of Japanese plants this way and through him, Houttuyn. Thunberg used the next occasion to return with the Dutch fleet to Batavia, where he arrived on 4 January 1777 (Thunberg, 1796, vol. 4 : 158). If a Chinese junk would have taken Houttuyn's Japan collections to Batavia, it could have been shipped with the return fleet of October-November 1776 that arrived in the Netherlands in May-June 1777 (Bruijn et al., 1979, vol. 3 : 500-503). Another possibility is that Thunberg brought the herbarium with him to Batavia and was just in time to send it with the last ships of the fleet that departed on 27 January 1777 and arrived in the Netherlands in September-October 1777. With these ships, Thunberg sent his Japanese material to the Burmans in Amsterdam. He announced the shipment in a letter dated 25 January 1777, two days before the ships sailed. The consignment consisted of one box with mounted herbarium specimens for the Burmans, four small boxes with seeds for the Hortus and his patrons, and one box with living trees, shrubs, and perennials for the same.
The conclusion based on the various possibilities for shipment mentioned above is that Houttuyn received his Japanese collections before June 1777, as the first mention of a Japanese specimen from his own herbarium is in Nat. Hist. II(7): 702, tab. 43, fig. 1, published 11 June 1777 (see Celosia japonica Houtt. below under $n^{\circ} 26$ ). The publisher's notice for part 8 is the first that mentions Japanese plants (FUCHs, 1962: 44). A comparison of Houttuyn's discussions on Japanese plants with Thunberg's Flora japonica (1784) shows that Houttuyn's material originated almost exclusively from the vicinity of Nagasaki. Only Viola birta sensu Houtt. (Nat. Hist. II(11): 132-133. 1779) [non $V$. hirta L.] was collected "circum Iedo [Edo]" (Thunberg, 1784: 326), indicating that this species may have been collected during his visit to the court there. A comprehensive analysis of the plants described on the basis of Thunberg's collections in Japan has been published by Wijnands (1990b).

The specimens in Thunberg's Japanese herbarium in UPSTHUNB are available online (EBIHARA et al., 2016).

\section{The Java herbarium}

In the auction catalogue, HoutTuYn (1789a: 12) wrote that his Java herbarium was "mainly collected by Mr. Thunberg in the Island of Java, in the surroundings of Batavia [Jakarta] and Semarang [C. Java] as well as in the Mountains southwards". It appears from the Natuurlijke Historie that Richter and Radermacher also contributed to it.

The identity of Richter is still obscure. According to Houttuyn (Nat. Hist. II(2): 52-53. 1774), he was Second Surgeon in the service of the Dutch East India Company at Batavia, where he was active for many years in the pharmacy as well as the hospital. Possibly he is the same person as Benjamin Richter, Surgeon-major of the Lifeguards of the Dutch Governor General, who had his will drawn up on 27 January 1747 (ARA, VOC 6851, n 1581). One of the nominated executors of this will was Christiaan Kleynhoff, at the time First Dressing-master of that hospital, who later on became a well-known collector of the Asian plants donated to Johannes Burman and Carl Linnaeus Sr. (FLoRiJn, 1986). According to Houttuyn (Nat. Hist. II(2): 52-53. 1774), Richter returned to the Netherlands in 1773 with a collection of plant specimens. He donated part of this to Andreas Bonn (17381817 ?), who was Professor of Anatomy and Surgery since 1771 at the Athenaeum Illustre in Amsterdam and at the Hortus Botanicus. Bonn gave his share of Richter's specimens on extended loan to Houttuyn, who dedicated his volumes on botany to both the Burmans and Bonn. But Houttuyn also received specimens as a gift from Richter. In the Natuurlijke Historie he discussed, for example, Jambolifera pedunculata sensu Houtt. [non J. pedunculata L.] (Houttuyn placed it in Rutaceae but is actually a Myrtaceae, Syzygium cuminii (L.) Skeels), Limonia diphylla Houtt., Psidium cujavillus Burm. f., 


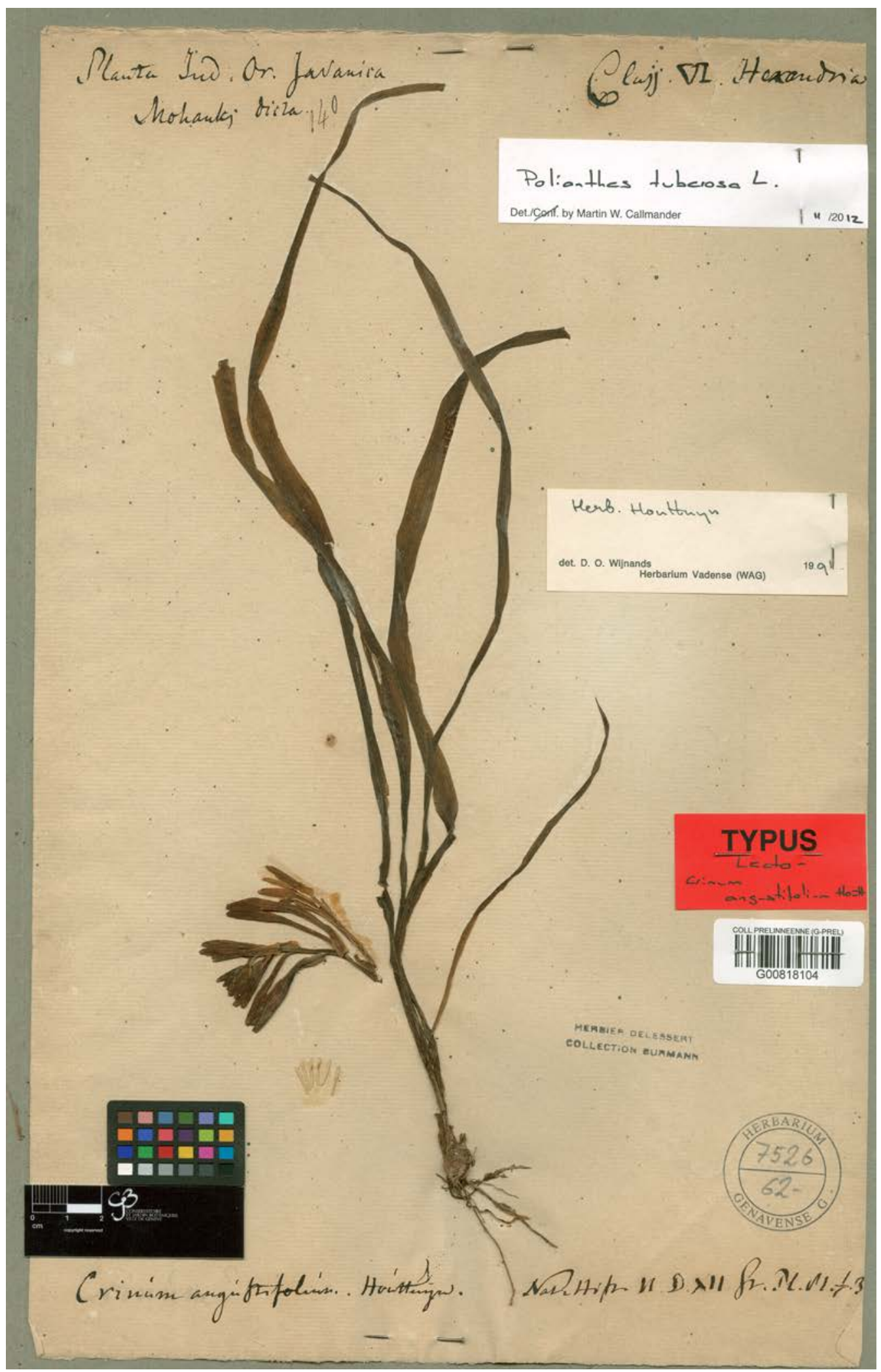

Fig. 3. - Lectotype of Crinum angustifolium Houtt. in Houttuyn's Java herbarium in G-PREL. 
Melaleuca leucadendra (L.) L., and Rondeletia asiatica L. A specimen of Vitex trifolia L. is present in L (L-908.267-566: "Ex Java per Richterum allata. 1773") (see also Hallier f., 1918, as cited by van Steenis-Kruseman, 1950: 435, under V. bicolor Willd.). H.J. Lam labelled this specimen as $V$. negundo var. bicolor H.J. Lam, but this taxon is now considered to be a synonym of Vitex trifolia.

Another part of Houttuyn's Java herbarium originated from Radermacher, one of the last vigorous high officials of the VOC. He arrived at Batavia in 1776, where he initially served as Bailiff of that town, and in 1776 ? he was promoted to Extraordinary Council of the Indies. Radermacher was a keen amateur botanist who contributed substantially to the foundation of the first Botanical Garden of the Batavian Society of Arts and Sciences at Buitenzorg (Bogor). He shipped at least two collections of specimens from Java to Houttuyn. In 1775 (Nat. Hist. II(5) : 337-338, tab. 26, fig. 2), discussing Volkameria serrata L., Houttuyn mentioned a fruiting branch under the vernacular name "Pegougoet, with many other rare plants sent from East India by the most respected Mr. Radermacher, bailiff at Batavia". Founding the genus Assa Houtt. (Nat. Hist. II(5): 274. 1775 ; = Tetracera L.), he stated that he was describing "a plant of which I receive a small branch from East India at present". VAN SteEnis \& VeldKamp (1973: 151) assumed that Houttuyn's type specimen of Assa indica Houtt., found by Hoogland in $\mathrm{L}$, was collected by Thunberg, but this cannot be correct. Thunberg's first visit to Java was from 18 May to 21 June 1775 (Thunberg, 1796, 2: 226, 401). The next fleet bound for Holland left Batavia in October-November 1775 and arrived in late spring 1776 in Holland (Bruijn et al., 1979, vol. 3 : 504-507), some months after Houttuyn's publication of Assa. Thus, more likely, it was Radermacher who collected the specimens shortly before 1775 .

The second collection that Radermacher sent to Houttuyn was mentioned in 1777 (Nat. Hist. II(7): 539-540, tab. 42, fig. 1; Convolvulus obscurus L.), "in the beautiful collection of East Indian plants, kindly delivered to me by J.C.M. Radermacher Esq., Extraordinary Councillor of Dutch India, this year, I find a species of Bindweed". Houttuyn's type specimen of Ipomoea pilosa Houtt. (Nat. Hist. II(7) : 573-574, tab. 42, fig. 2. 1777), "from my said East India collection", probably formed part of this Radermacher shipment as well, although there is a possibility that Thunberg made this collection. On his way back from Japan, Thunberg arrived on 4 January 1777 at Batavia and was frequently invited for dinner by Radermacher (THUNBERG, 1796, vol. 4: 162-163). The last ships that could have reached Holland in 1777 left from Batavia on 27 January (BruijN et al., 1979, vol. 3: 504-505).

The third part of Houttuyn's Java herbarium consists of Thunberg's collections from the surroundings of Batavia and Semarang. Radermacher and Friedrich Baron von Wurmb
(1742-1781) (not mentioned by van Steenis-Kruseman, 1950) joined him and their collections may make part of this herbarium. When and how Houttuyn received these specimens cannot be ascertained from the available evidence.

Thunberg's trip to Semarang lasted from 23 March to 1 June 1777 (Thunberg, 1796, vol. 4 : 164-188). The first opportunity to ship plants from there to Holland was the fleet of October-November 1777, mentioned above. However, Houttuyn (1778) discussed in part II(9 and later ones) many of his specimens from Java, but he did not mention Thunberg as the collector. Only in 1783, in parts 13 and 14 on grasses, ferns, mosses, and lichens, did he cite many specimens as being collected by Thunberg in Java. Our provisional conclusion must therefore be that Radermacher presented these to Houttuyn directly or more likely indirectly between 1778 and 1783. Quite a few Thunberg collections from Java are present in L, e.g. Boerhavia diffusa L. (van Steenis \& Veldkamp, 1973: 151) from the vicinity of Semarang.

\section{Houttuyn's systematic botany legacy}

\section{Nomenclature of Houttuyn's names}

The botanical part of Natuurlijke Historie was published between 1773 and 1783. In many cases Houttuyn described new species on the basis of Thunberg's specimens before Linnaeus f. (1782), Murray (1784), or Thunberg (between 1784 and 1825) did; see Merrill $(1938,1939)$ for a discussion of this. Sometimes Houttuyn coined the names himself, in other cases he adopted Thunberg's binomials written on the sheets or from oral suggestions made when Thunberg visited him in October 1778. In these cases the correct author citation is "Houtt." Only in those instances where Houttuyn quoted Thunberg as the origin of a name may the citation "Thunb. ex Houtt." be used (McNeill et al., 2012: Art. 46.5) (see Acrostichum hastatum Thunb. ex Houtt. below under $\mathrm{n}^{\circ} 2$ for an example). Houttuyn based his names primarily on the material in his possession but also from other Dutch herbaria, e.g. those of the Burmans, father and son, Johan Frederik Gronovius (1686-1762), and the van Royens. We have not found a connection with Clifford. This association with the Burmans might explain the presence of Houttuyn material in AMD (now at L), although no sheets bear any indication of ever having been part of their herbarium (WIJNANDs, 1987).

The identical but later names published by Linnaeus $\mathrm{f}$. and Thunberg are based on the specimens in their own herbaria, and although some might consider them to be homonyms, we regard them as isonyms because their types are duplicates of the same gatherings (see Art. 6.3, note 2). This may cause troublesome complications, because many later authors referred to Linnaeus $f$. and Thunberg since Houttuyn's publications were generally unknown, a situation that has persisted until now. Examples include, for instance Acrostichum hastatum and 


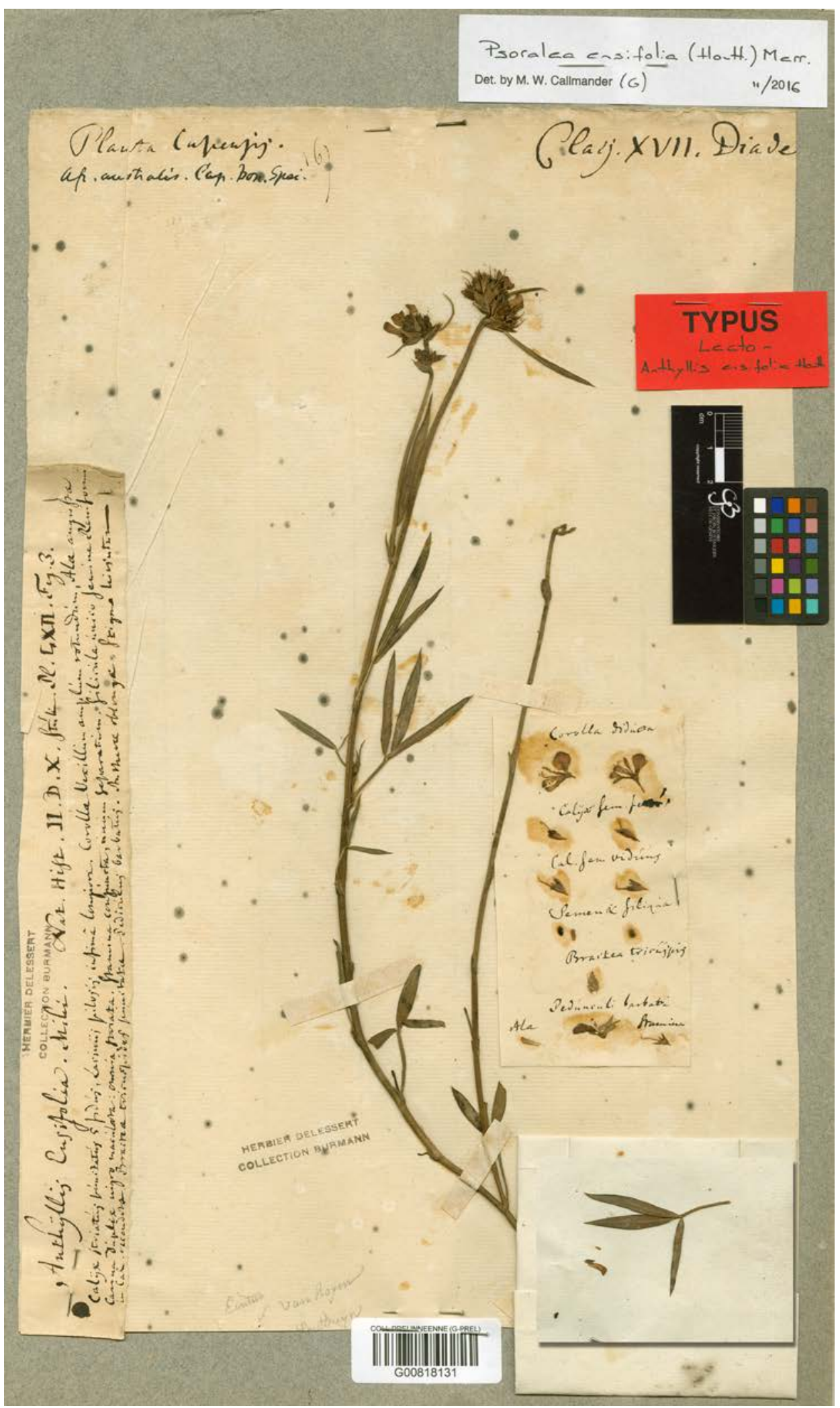

Fig. 4. - Lectotype of Anthyllis ensifolia Houtt. in Houttuyn's Cape herbarium in G-PREL. 
Bromus japonicus Houtt. (1782), while more than 50 infraspecific taxa have been described under the later isonym B. japonicus Thunb. (1784). These names are legitimate according to Art. 55.2: the authorship of the specific name may be corrected, the later one being an isonym without nomenclatural status (Art. 6.3, note 2).

Typification of the names listed below follows the International Code of Nomenclature (McNeILl et al., 2012) and the very useful user's guide by TurLand (2013). As indicated above, the main set of the Houttuyn herbarium has been located and is now part of the Pre-Linnaean collection in Geneva (G-PREL). Nevertheless, because of the complex history of the specimens that Houttuyn may have used for his discussions in the Natuurlijke Historie and the fact that several original sheets have been trimmed and possibly split, we have chosen to designate lectotypes even though the vast majority of the names published by Houttuyn are associated to a single gathering of original material in G-PREL, generally with Houttuyn's handwriting, although the Natuurlijke Historie plates can also be considered as part of the original material. Designating original specimens from Houttuyn's herbarium as lectotypes will avoid any future doubts about the typification of his binomials. Any duplicates deposited elsewhere (e.g. in UPS-THUNB) are thus iso(lecto)types. For names validated by Thunberg, original material now at UPS-THUNB is considered to represent material used by him (Art. 9.1). Therefore, if a single gathering is present at UPS-THUNB, it is considered as the holotype and any duplicates in G-PREL as isotypes.

Citations of the Natuurlijke Historie presented in the section below follow the abbreviations used above in this paper. Nat. Hist. II(5) refers to Natuurlijke Historie II, vol. 5, etc. (Houttuyn, 1773-1783a) and Aanwyz. Plaat. refers to the unpaged pamphlet (pages indicated below between square brackets) that contained instructions to the binder, which may be absent in some copies or bound in an unspecified place in others. Specimens from $\mathrm{L}$ are cited by their sheet numbers (within brackets) because they were quoted as such in the original manuscript left by the first author. Today they have $\mathrm{L}$ barcodes, which unfortunately have not been linked to the sheet numbers. Specimens from $G$ are cited with their respective barcodes (within square brackets). UPS-THUNB specimens are cited by their assigned numbers in the Thunberg herbarium.

Cape, Ceylon, Japan, and Java herbaria refer to the different parts of Houttuyn's herbarium (see above). Appendix II presents an index of all 111 names cited below with their current usage (accepted names and heterotypic synonyms) sorted by families.

\section{Lectotypifications and miscellaneous notes associated with Houttuyn's herbarium and names}

1. Abrus precatorius L., Syst. Nat. ed. 12, 2: 472.1767 [cited in Nat. Hist. II(5): Aanwyz. Plaat. [2], 436, tab. 37, fig. 3. 1775].

Notes. - Houttuyn's plate was based on a specimen from China (collected by Osbeck?) (see van Steenis-Kruseman, 1950: 395), but there is a specimen in G-PREL [G00818009] from his Ceylon herbarium. Two additional specimens from Ceylon are present in the Thunberg herbarium (UPS-THUNB $n^{\circ} 16299$ and $n^{\circ} 16300$ ).

2. Acrostichum bastatum Thunb. ex Houtt., Nat. Hist. II(14): Aanwyz. Plaat. [1], 68, tab. 95, fig. 2. 1783.

$\equiv$ Pyrrosia hastata (Thunb. ex Houtt.) Ching in Bull. Chin. Bot. Soc. 1: 48. 1935.

Lectotypus (first step designated by VeLdKAmp, 2004 : 191; second step designated here by Wijnands,Veldkamp, Callmander \& Fumeaux): JAPAN: Thunberg s.n. (G-PREL [G00818012]! ; isolecto- : UPS-THUNB $n^{\circ} 24584$ image seen) (Fig. 5).

Notes. - The type material is present in the Japan herbarium in G-PREL with Thunberg's handwriting, and was found by the first author (Fig. 5). Thunberg (1784: tab. 34) published an illustration of his later isonym that appeared in MURRAY (1784: 928), and original material was located in UPS-THUNB. Hoven Kamp (1986: 186) designated Houttuyn's plate as the lectotype. However, since the original specimen from which the illustration clearly was made has been located, the lectotypification was superfluous (see Art. 9.19).

In reality, the situation is more complicated, as fully discussed by VeldKamp (2004), who erroneously assumed that Acrostichum hastatum Thunb. ex Houtt. and A. hastatum Thunb., both based on Thunberg collections, "might quite possibly be parts of the same gathering" (Art. 8.2). But he went on to write that "because these combinations were based on different specimens deposited in different places" they would be "heterotypic, synonymous homonyms", as has previously been pointed out by TAgAwA (1957: 354).

This is not in agreement with Art. 9.3. Accordingly, here and elsewhere, the specimens collected by Thunberg and used by Houttuyn and by Thunberg are regarded as duplicates of the same gathering. Houttuyn's names are generally the older ones (see Osmunda japonica Houtt. below under $n^{\circ} 76$ for an exception). In the present case, the name published by Thunberg is an isonym with no nomenclatural status (Art. 6.3 Note 2). The author citation should therefore be adjusted (but see above), making the correct name Pyrrosia hastata, by which name this ornamental species is universally known. 


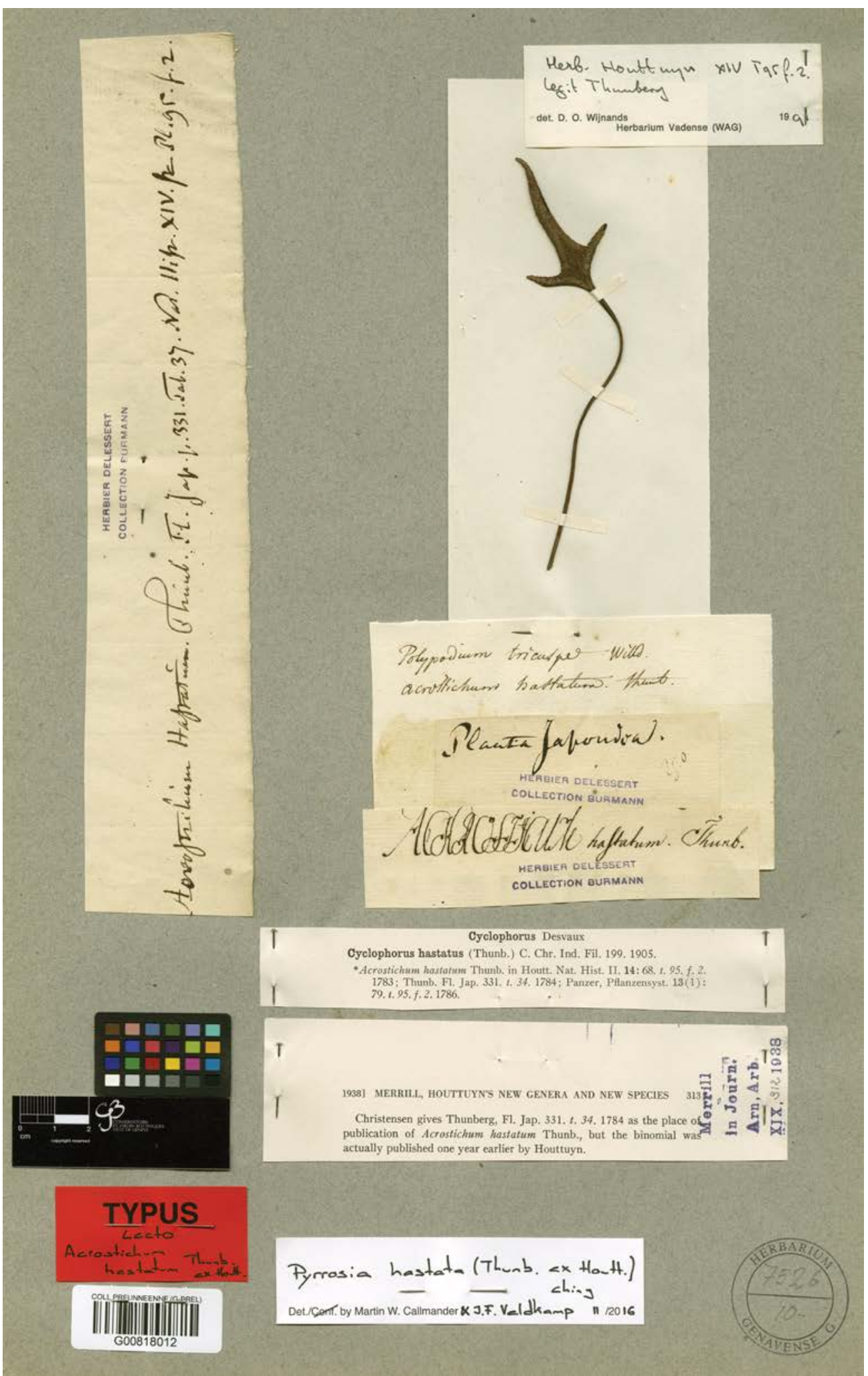

Fig. 5. - Lectotype of Acrostichum hastatum Thunb. ex Houtt. in Houttuyn's Japan herbarium in G-PREL. 
3. Agrostis javanica Houtt., Nat. Hist. II(13): Aanwyz. Plaat. [2], 225, tab. 90, fig. 5. 1782.

Lectotypus (designated here by Veldkamp \& Callmander): INDONESIA. Java: Thunberg s.n. [?] (G-PREL [G00818013]!).

= Ischaemum muticum L., Sp. Pl.: 1049.1753.

Notes. - Merrill (1938: 319) discussed the G-PREL specimen but did not recognise it as Houttuyn's. A Houttuyn specimen of Agrostis javanica in L (L-908.77-91) represents Zoysia matrella (L.) Merr. (GoudswaArd, 1980: 170) with watermark "IV" (Jean Villedary). The single gathering present in the Houttuyn herbarium in G-PREL is designated here as the lectotype.

4. Aira arundinacea sensu Houtt., Nat. Hist. II(13): Aanwyz. Plaat. [2], 229, tab. 91, fig. 1.1782 [non $A$. arundinacea L.].

= Panicum bisulcatum Thunb. in Nova Acta Regiae Soc. Sci. Upsal. 7: 141. 1815. Lectotypus (designated here by Veldkamp \& Callmander): JAPAN: Thunberg s.n. (UPS-THUNB $\mathrm{n}^{\circ} 1817$ image seen; isolecto- : G-PREL [G00818157]!, UPS-THUNB n 1818 image seen).

Notes. - Houttuyn's text here is rather complicated and one may have trouble interpreting what exactly he was trying to convey. We have concluded that in Aanwyz. Plaat. he did not propose Aira arundinacea as a name for the "Japansch Rietgras", but that plate 91 with an illustration of the latter had to be placed opposite ("tegenover", Aanwyz. Plaat. [2]) or next to ("nevens", Nat. Hist. II(13): 229.1782) the citation of A. arundinacea ("aangehaald", Aanwyz. Plaat. [1]).

Houttuyn discussed on pp. 229-230 three species under the heading Aira arundinacea. The first is the Linnaean one from the Near East, the "Levantsch", now Eragrostis collina Trin. Linnaeus, cited by Houttuyn, gave the phrase name "AIRA panicula oblonga secunda mutica imbricata, foliis planis", suggesting that he had seen more than just Tournefort's phrase name "Gramen orientale paniculatum, portulacea semine", where these characters are not mentioned. However, there is no specimen present in the Linnaean herbarium and he could never have seen that of Tournefort. In the absence of further data, there was little that Houttuyn could have added.

The second "Rietgras", "Indisch", is mentioned in a sentence that is grammatically incorrect. It would seem that it should have begun with something like "Voor" [in place of]. The species clearly is Aira indica L., with a somewhat complicated nomenclatural history, which is beyond the present discussion. Houttuyn said he had transferred it to the "Trosachtig of Gekropte Panikgras", i.e. Panicum conglomeratum L., "Trosachtig [panikgras]” found in Nat. Hist.
II(13): 178. 1782. This is now known as Sacciolepis indica (L.) Chase. Instead, Houttuyn replaced the latter by a very beautiful "Japansch Rietgras", which he said had much similarity in growth with the "Levantsch", according to the diagnosis ("bepaling"). A description of his own Thunberg specimen in the Japan herbarium in G-PREL [G00818157] follows. No combination is proposed for it here.

In the Thunberg herbarium, there are two duplicates (UPSTHUNB n 1817 and 1818) on which Thunberg based his Panicum bisulcatum and from which the lectotype has been selected.

5. Amaranthus mangostanus sensu Houtt., Nat. Hist. II(11): Aanwyz. Plaat. [2], 254, tab. 72, fig. 1.1779 [non A. mangostanus L.].

= Amaranthus interruptus R. Br., Prodr.: 414. 1810.

Notes. - There is a collection in the Japan herbarium collected by Thunberg (G-PREL [G00818105]). It is a good match for the plate.

6. Amaryllis dubia Houtt., Nat. Hist. II(12): Aanwyz. Plaat. [2], 181, tab. 82, fig. 1.1780 [non A. dubia L.].

Lectotypus (designated here by Wijnands) : SouTH AfricA: Cape, Auge s.n. [?] (G-PREL [G00818014]!).

= Nerine sarniensis (L.) Herb. in Bot. Mag.: sub tab. 2124. 1820.

Notes. - A single element of original material is present in the Cape herbarium. This collection is designated here as the lectotype.

7. Anacardium occidentale L. Sp. P1.: 383.1753 [cited in Nat. Hist. II(2): Aanwyz. Plaat. [2], 409, tab. 9, fig. 1. 1774].

Notes. - Houttuyn's plate represents a fruit and its cross section. There is an unannotated specimen from his Ceylon herbarium in G-PREL [G00818015]. Another specimen from Ceylon is in the Thunberg herbarium (UPS-THUNB $\left.n^{\circ} 24033\right)$.

8. Anemone japonica Houtt., Nat. Hist. II(9): Aanwyz. Plaat. [2], 191, tab. 55, fig. 1. 1778.

$\equiv$ Clematisflorida Thunb. in Murr., Syst. Veg. ed. 14: 512. V-VI.1784.

Lectotypus (designated here by Veldkamp) : JAPAN : Thunberg s.n. (G-PREL [G00818016]!; isolecto- : UPSTHUNB n ${ }^{\circ} 13017$ !). 
Notes. - The type specimen of Anemone japonica from Japan was collected by Thunberg. WiJnands $(1988: 3,5)$ equated this with Clematis florida Thunb., a name that is also cited in Thunberg (VIII.1784: 240). Clematis florida is the accepted name as Houttuyn's epithet in Clematis L. is preceded by C. japonica Thunb. published in Murray (1784: 512). Its type specimen is in the Thunberg herbarium (UPS-THUNB $n^{\circ}$ 13023). Following to our remarks under Acrostichum hastatum above, these specimens are duplicates of each other and the combinations are homotypic.

9. Anthericum bulbine Houtt., Nat. Hist. II(12): Aanwyz. Plaat. [2], 353, tab. 80, fig. 3. 1780.

Lectotypus (designated here by Veldkamp \& Callmander): South Africa: Cape, Auge s.n. [?] (G-PREL [G00818006]!; probable isolecto-: G-PREL [G00818007, G00818008]!).

$=$ Pontederia stricta Burm. f., Fl. Ind. (Prodr. Fl. Cap.): 9. 1768. $\equiv$ Onixotis stricta (Burm. f.) Wijnands in Bothalia $21: 157.1991 . \equiv$ Wurmbea stricta (Burm. f.) J.C. Manning \& Vinn. in Taxon $56: 177.2007$. Lectotypus (first step designated by WiJNANDs, 1991: 157; second step designated here by Wijnands \& Callmander): South AFrICA: Cape, Auge s.n. (G-PREL [G00818007]!; probable isolecto-: G-PREL [G00818006, G00818008]!).

Notes. - The lectotype of Anthericum bulbine is in the Cape herbarium, probably collected by Auge (WIJnAnds, 1991 : 157; 1992: 499). We may never be certain whether Houttuyn's name is a later heterotypic synonym, as it is probably also based on an Auge specimen. It is not a nom. provisorium, because although he indicated that "Possibly [!] the Cape plant will belong to one of the species mentioned", he did accept it (McNeill et al., 2012: Art. 36.1). A second step lectotypification of Pontederia stricta is made here as two collections are present in the Burman herbarium in G-PREL [G00818007, G00818008].

10. Antholyza aletroides Burm. f., Fl. Ind. (Prodr. Fl. Cap.): 1. 1768.

=Watsonia aletroides (Burm. f.) Ker Gawl. in Bot. Mag.: tab. 533. 1801.

Lectotypus (first step designated by Goldblatt, 1989: 50 ; second step designated here by Veldkamp \& Callmander): South AFrica: Cape, Auge s.n. [?] (G-PREL [G00818018]! ; isolecto- : G-PREL [G00818017, G00818019, G00818020]!).
Notes. - Goldblatt (1989: 50) cited a Burman herbarium s.n. collection as the lectotype. This implicit lectotypification requires a second step because four collections are present in G-PREL from two different origins: 3 from the Burman herbarium and one from the Houttuyn herbarium [G00818017]. The lectotype designated here is the most complete collection from the Burman herbarium. The Cape herbarium collection is very likely a duplicate as all four collections were very likely collected by Auge (see Anthericum bulbine above under n ${ }^{\circ}$ ).

11. Antholyza caryophyllacea Burm. f., Fl. Ind. (Prodr. Fl. Cap.): 1.1768 .

$\equiv$ Gladiolus caryophyllaceus (Burm. f.) Poir. in Lam., Encycl. Suppl. 2: 795.1812.

Lectotypus (designated by Lewis \& Obermeyer, 1971: 114) : South Africa: Cape, Auge s.n. [?] (G-PREL [G00818021]!; isolecto- : G-PREL [G00818022]!).

Notes. - Lewis \& Obermeyer (1971: 114) designated a specimen in Houttuyn's Cape herbarium preserved in G-PREL as the lectotype. The designation of a clear single specimen makes this lectotypification perfectly valid but unfortunate. Indeed, another specimen in the Burman herbarium with the handwriting of Burman $\mathrm{f}$. is present in G-PREL [G00818022], which should have been considered for the lectotype. As both specimens are very likely duplicates collected by Auge, the latter must be considered to be an isolectotype.

12. Anthyllis ensifolia Houtt., Nat. Hist. II(10): Aanwyz. Plaat. [2], 120, tab. 62, fig. 3. 1779.

$\equiv$ Psoralea ensifolia (Houtt.) Merr. in J. Arnold Arbor. 19: 348. 1938.

Lectotypus (designated here by Callmander) : SouTH Africa: Cape, Auge s.n. [?] (G-PREL [G00818131]!) (Fig. 4).

Notes. - A single collection of original material is in the Houttuyn Cape herbarium in G-PREL. It is a good match for the plate and is designated here as the lectotype (Fig. 4).

13. Apocynum frutescens L., Sp. Pl.: 213. 1753 [cited in Nat. Hist. II(7): 746. 1777].

$\equiv$ Ichnocarpus frutescens (L.) W.T. Aiton, Hort. Kew ed. 2, 2: 69. 1811.

Notes. - A specimen in the Ceylon herbarium is in G-PREL [G00818025]. Two Thunberg specimens from Ceylon have been located in the Thunberg herbarium (UPSTHUNB n 6198 and n 6199). 
14. Arctotis aspera L., Sp. P1.: 922.1753 [cited in Nat. Hist. II(11): 90.1779].

Notes. - A specimen is present in the Cape herbarium in G-PREL [G00818026]. Two Thunberg collections are also present in the Thunberg herbarium (UPS-THUNB n 20748 and $n^{\circ} 20749$ ).

15. Argostemma borragineum Blume ex DC., Prodr. 4: 417. 1830.

Notes. - A specimen from the Java herbarium is in $\mathrm{L}$ (L-908.352-509). It was collected in the mountains south of Batavia and bears the watermark "IV" (Villedary).

16. Aspalathus fascicularis Burm. f., Fl. Ind. (Prodr. Fl. Cap.): 21. 1768.

Lectotypus (designated here by Callmander) : SouTH Africa: Cape, Auge s.n. [?] (G-PREL [G00818024]!).

Notes. - Aspalathus fascicularis was cited by DAhlgren (1963: 252) as a nom. dubium and not treated in his twelve papers published in Botaniska Notiser and Opera Botanica [see VAN WYK (1987) for a complete list of Dahlgren's publications]. The Houttuyn specimen from the Cape in G-PREL was determined in 1959 by Dahlgren as $A$. vermiculata Lam. and is designated here as the lectotype. Aspalathus fascicularis should be regarded as the correct name for the taxon often referred to by the later name $A$. vermiculata Lam.

17. Aspalathus multiflora Thunb., Prodr. Fl. Cap. 2:128. 1800.

Lectotypus (designated by Dahlgren, 1968: 60): SOUTH AFrICA: "Cap. b. spei a", Thunberg s.n. (UPS-THUNB n 16487 image seen; isolecto-: LD-1241837 image seen).

= Aspalathus vermiculata Lam., Encycl. 1:288. 1783.

Notes. - Two collections are present in UPS-THUNB. One is identified as Aspalathus vermiculata Lam. by W.H. Harvey and was designated as the lectotype by DAHLGRen (1968: 60). The second collection was identified as A. thymifolia var. albiflora (Eckl. \& Zeyh.) Harv. by W.H. Harvey (see Harvey, 1862). The collection in LD is stamped "Museum Acharianum" and is therefore regarded here as an isolectotype, given that "Acharius and Thunberg were close friends and exchanged material", according to Nordenstam \& Buys (2011: 1191).
18. Aspalatbus pedunculata Houtt., Nat. Hist. II(5): Aanwyz. Plaat. [3], 475, tab. 28, fig. 2. 1775.

Lectotypus (designated by DAHLGREN, 1968: 70): SOUTH AFrICA: Cape, Auge s.n. [?] (G-PREL [G00818023]!).

Notes. - The lectotype is in the Cape herbarium and represents a clear match for the plate. Merrill's (1938: 345) interpretation of this plate as Aspalathus divaricata Thunb. is incorrect. The type specimen of $A$. squamosa Thunb. in the Thunberg herbarium (UPS-THUNB ${ }^{\circ}$ 16508) was identified as $A$. pedunculata by W.H. Harvey, but Dahlgren (1960: 313) equated it with $A$. bracteata Thunb.

19. Assa indica Houtt. ex Christm. \& Panz., Vollst. Pflanzensyst. 4 : 40, tab. 26 , fig. 1.1779 .

$\equiv$ Tetracera indica (Houtt. ex Christm. \& Panz.) Merr., Interpr. Herb. Amboin.: 367. 1917.

Lectotypus (designated by Hoogland, $1953: 207$ ) : INDONESIA.Java: Radermacher s.n. [?] (L-902.111-291!).

Notes. - The genus Assa Houtt. was validly published by Houttuyn in Natuurlijke Historie (Nat. Hist. II(5): 275. 1775) with no designation of a type species. It is now accepted under the Linnaean name Tetracera L.

Assa indica was published four years later by CHRIsTmanN \& PAnzer (1777-1788). A Thunberg specimen (the type of Wablbomia indica Thunb.) is in the Thunberg herbarium (UPS-THUNB ${ }^{\circ}$ 12837), which is not a duplicate as it was collected by Thunberg after 1775 .

20. Athanasia pubescens sensu Houtt., Nat. Hist. II(6): 39.1776 [non A.pubescens (L.) L.].

$=$ Athanasia tomentosa Thunb., Prodr. P1. Cap.: 144.1800. Typus : SouTH AFrica: Cape, Thunberg s.n. (holo- : UPS-THUNB nº 18960 image seen).

Notes. - A specimen in the Cape herbarium is in G-PREL [G00818027]. It belongs to Athanasia tomentosa but is probably not a duplicate of the Thunberg collection at UPS-THUNB.

21. Atractylis angustifolia Thunb. ex Houtt., Nat. Hist. II(10): Aanwyz. Plaat. [3], 518, tab. 67, fig. 1. 1779.

$\equiv$ Berkheya angustifolia (Thunb. ex Houtt.) Merr. in J. Arnold Arbor. 19: 369.1938.

Lectotypus (designated here by Veldkamp \& Callmander): SouTH AFRICA: Cape, Thunberg s.n. (G-PREL [G00818028]!). 
Notes. - Original material is present in the Cape herbarium, and the single collection is designated here as the lectotype. There appears to be no corresponding specimen in UPS-THUNB. Only two sheets of Atractylis humilis L. have been located (UPS-THUNB n ${ }^{\circ} 18590$, Spain; UPS-THUNB $\mathrm{n}^{\circ}$ 18591, sine loco).

22. Averrboa carambola L., Sp. P1.: 428.1753 [cited in Nat. Hist. II(2): 477. 1774].

Notes. - A specimen in the Java herbarium, annotated by Houttuyn "omstreeks Batavia" [around Batavia], is in G-PREL [G00818029]. Two specimens are also present in the Thunberg herbarium: UPS-THUNB $n^{\circ} 10989$ in the Java herbarium and UPS-THUNB n 10999 from Ceylon.

23. Boerhavia diffusa L., Sp. P1.: 3.1753 [cited in Nat. Hist. II(7): 43. 1777].

Notes. - A specimen in the Java herbarium, annotated as such by Thunberg, is in L (L-908.157-428) (see van STEEnIS \& VeLDKAMP, 1973:151). A specimen without provenance is present in the Thunberg herbarium (UPS-THUNB n ${ }^{\circ}$ 65). Three collections are in the Houttuyn herbarium in G-PREL, respectively determined in Houttuyn handwriting as B. diffusa [G00818030], B. hirsuta L. [G00818032], and B. erecta L. [G00818031].

24. Bromus japonicus Thunb. ex Houtt., Nat. Hist. II(13): Aanwyz. Plaat. [2], 315, tab. 91, fig. 4. 1782.

Lectotypus (designated here by Veldkamp) : JAPAN : Thunberg s.n. (G-PREL [G00380028]!; isolecto-: UPSTHUNB n 2503 image seen).

Notes. - The priority of the Houttuyn name has been overlooked by almost everyone, even Merrill (1938), with the exception of a casual mention by NAKAI (1952: 136). Thunberg in Murray (1784: 119) described the isonym Bromus japonicus Thunb. (also cited in Thunberg, $1784: 52$, tab. 11). The type material of Houttuyn's earlier name is in the Japan herbarium in G-PREL. PÉnzes $(1936: 18)$ cited the type of Thunberg's isonym at UPS-THUNB. This collection is here considered as an isolectotype.
25. Caucalis japonica Houtt., Nat. Hist. II(8): Aanwyz. Plaat. [1], 42, tab. 45, fig. 1. 1777.

$\equiv$ Torilis japonica (Houtt.) DC., Prodr. 4:219.1830.

Lectotypus (designated here by Veldkamp) : JAPAN : Thunberg s.n. (G-PREL [G00096184]!; isolecto- : G-PREL [G00818003] specimen A!).

Notes. - The lectotype is in the Japan herbarium in G-PREL. According to a label on the sheet, there should be another specimen under T. scabra. This is G-PREL [G00818003], labelled as Chaerophyllum hirsutum L. by Thunberg; it is a mixture of "A": Torilis japonica and "B": Torilis scabra (Thunb.) DC. in A.-P. de Candolle's handwriting.

In the Thunberg herbarium there are two sheets of Chaerophyllum hirsutum without provenance (UPS-THUNB ${ }^{\circ} 7164$ and $\mathrm{n}^{\circ}$ 7165), which might be duplicates of the G-PREL collection.

26. Celosia japonica Houtt., Nat. Hist. II(7): Aanwyz. Plaat. [2], 702, tab. 43, fig. 1. 1777.

Lectotypus (designated here by Callmander \& Fumeaux): JAPAN: Thunberg s.n. (G-PREL [G00818101]!).

$=$ Celosia pyramidalis Burm. f., Fl. Indica: 65, tab. 25, fig. 1.1768 [cited in Nat. Hist. II(7) : 705]. 1777. Lectotypus (designated here by Callmander \& Fumeaux): [INDONESIA. Java]: (Burman f., Fl. Indica: tab. 25, fig. 1.1768).

$=$ Celosia argentea L., Sp. P1.: 205.1753.

Notes. - Original material of Celosia japonica accepted under the Linnaean name $C$. argentea is present in G-PREL. The sole collection in the Japan herbarium collected by Thunberg is designated here as the lectotype of C. japonica. A Thunberg collection annotated by himself and Houttuyn as "Celosia pyramidalis Burm." is in the Java herbarium in G-PREL [G00818112]. This collection cannot be considered as original material as the name is based on a cultivated plant originating from seeds collected in Java and grown at the Botanical Garden in Amsterdam (original description and Nat. Hist. II(7): 705. 1777). Figure 1 of plate 25 in Flora Indica by Burman f. is therefore designated as the lectotype in the absence of any original material.

A Pryon collection is present in the Burman herbarium (G-PREL [G00818142]), annotated by Pryon as "Amarantus foliis angustis, pyramidalis flagellis, luteo purpureis".

There is a specimen in UPS-THUNB with no indication of its provenance (UPS-THUNB n ${ }^{\circ}$ 5929). Another specimen was made from material grown much later in the Uppsala Botanical Garden (UPS-THUNB $n^{\circ}$ 5940); it has a fair resemblance to Houttuyn's plate.

Celosia japonica is the first report by Houttuyn of a specimen from Japan in his own herbarium (see introduction p. 162). 
27. Chaerophyllum scabrum Thunb. in Murr., Syst. Veg. ed. 14: 289. V-VI.1784.

$\equiv$ Torilis scabra (Thunb.) DC., Prodr. 4: 219-220.1830.

Lectotypus (designated here by Veldkamp \& Callmander): JAPAN: Thunberg s.n. (UPS-THUNB n ${ }^{\circ} 7166$ !).

Notes. - Chaerophyllum scabrum was also cited in the Flora japonica (Thunberg 1784: 119). Two collections are present in the Thunberg herbarium, one collection from Japan and the other from a cultivated plant grown in Uppsala (UPSTHUNB $n^{\circ}$ 7167). We designate the former, from Japan, as lectotype. It is uncertain whether another specimen in G-PREL [G00818003 specimen B] is original material as its provenance is not given, but most likely it is an isolectotype.

28. Cineraria incisa Thunb. ex Houtt., Nat. Hist. II(10): 693. 1779.

Lectotypus (designated here by Wijnands) : SouTH AFrICA: Cape, Thunberg s.n. (G-DC [G00204742]!); isolecto-: UPS-THUNB n 19830 image seen).

$=$ Senecio erosus L. f., Suppl. P1.: 370.1782.

Notes. - Houttuyn wrote in Nat. Hist. II(10): 693. 1779 that "Mr. Thunberg recently has found yet a new one ... in my collections and had named it Cineraria incisa", followed by a brief diagnosis. Buried in the text, it is no wonder that even Merrill (1938) overlooked this name in his survey of Houttuyn's novelties. It is not mentioned in the survey by ARNOLD \& DE WET either (1993: 759).

Although Cineraria incisa was named by Thunberg when he visited Amsterdam in 1778, he did not publish it. Instead, he described the species as Doria incisa Thunb. based on Thunberg s.n. (UPS-THUNB n ${ }^{\circ}$ 19830) (Thunberg, 1800a: 156) and presumably again a little later (Thun berg, 1800b: 167). WiLLDENOW (1803: 2074), citing these two references, made the "new" combination Cineraria incisa (Thunb.) Willd., which is a later homonym, or perhaps even an isonym.

Candolle (1838: 438) based Brachyrhynchos trachycarpus DC. on a Houttuyn sheet in the Delessert herbarium, presumably the type material of Cineraria incisa Houtt., but did not mention that name. With a question mark he added Doria incisa and without any remark Cineraria incisa Willd. The only sheet in G-DC [G00204742] annotated as such ("Senecio trachycarpus / Cap / M. Delessert 1833") is a fragment bearing none of the characteristics of a Houttuyn sheet, but de Candolle cited it as "Cineraria incisa Houtt.! in h. Deless.", so we must assume that this remounted fragment is part of a specimen from Houttuyn's herbarium that remains untraceable to date (no further specimen has been located). For this reason, the fragment is therefore designated here as the lectotype. Regardless of whether this argument is accepted or not, Brachyrhynchos trachycarpus is in any case a superfluous name for either Cineraria incisa Houtt. or Doria incisa Thunb.

Brachyrhynchos trachycarpus was not mentioned by ARNOLD \& De WeT (1993: 769), but they did mention Doria incisa as a synonym of the earlier name Senecio erosus L. f. (Linnaeus f., 1782:370). The name S. erosus is not threatened by Cineraria incisa because of Senecio incisus Thunb. (Thunberg, 1800a: 158).

\section{Clerodendrum infortunatum L., Sp. P1.: 637.1753.}

Notes. - Two specimens in the Java herbarium are present in G-PREL [G00818035, G00818137] with no assigned collectors. Two other specimens collected by Thunberg are in the Ceylon herbarium [G00818138, G00818139], and two specimens are in the Thunberg herbarium (UPS-THUNB $\mathrm{n}^{\circ}$ 14591 and $n^{\circ}$ 14592) labelled "India orientalis", which suggests that these are not original Thunberg collections, as he usually labelled them as "Cap. b. spei", "Ceylon", "Japan", "Java". In Java, this name has been misapplied to C. viscosum Vent. (Backer \& Bakhuizen van Den Brink f., 1965 : 611 ; see Callmander et al., 2017).

30. Clerodendrum paniculatum L., Mant. Pl. 1: 90.1767 [cited in Nat. Hist. II(5): 342.1775].

Notes. - A specimen of this widespread Asian species ("Planta Ind. Orient. Loliamanta dicta") is in L (L-908.352522); Houttuyn did not discuss it. The vernacular name does not seem to be Malayan / Javanese, so it may have come from Ceylon. A Thunberg collection from Java (UPS-THUNB $\mathrm{n}^{\circ}$ 14593) bears what is presumably another vernacular name, "Noka nanta" (or a huge misreading?), and is therefore probably not a duplicate.

31. Clitoria ternatea L., Sp. Pl.: 753.1753 [cited in Nat. Hist. II(10) : 170. 1779].

Notes. - There is a specimen in the Ceylon herbarium in G-PREL [G00818033] and another one from Java in G-PREL [G00818034], annotated by Houttuyn as "Bonga $\mathrm{Bi}(\mathrm{r})$ ou". Two specimens from Java are present in the Thunberg herbarium (UPS-THUNB n 10843 and n ${ }^{\circ}$ 10844). 
32. Convolvulus batatas L., Sp. P1.: 154. 1753 [cited in Nat. Hist. II(7): 541. 1777].

$\equiv$ Ipomoea batatas (L.) Lam., Tabl. Encycl. 1: 465.1793.

Notes. - A specimen from the Japan herbarium is in G-PREL [G00818039]. It belongs to Stephania japonica (Thunb.) Miers. Two specimens are present in the Thunberg herbarium; one of them, collected by Thunberg from the Cape (UPS-THUNB n ${ }^{\circ} 4422$ ), is annotated as Convolvulus batatas.

33. Convolvulus capensis Burm. f., Fl. Ind. (Prodr. Fl. Cap.): 5. 1768 .

Lectotypus (designated by Meeuse \& Welman, 2000 : 40) : South Africa : Cape, Auge s.n. [?] (G-PREL [G00818038]!; isolecto- : G-PREL [G00818140]!).

Notes. - Meeuse \& Welman (2000: 40) implicitly designated a collection in the Houttuyn Cape herbarium as the lectotype. Another collection is present in the Burman herbarium and very likely represents a duplicate collected by Auge. The latter collection is here considered to be an isolectotype and would have been a better choice for the lectotypification. Wood et al. (2015) also cite the Cape herbarium specimen as the type in their monograph of the genus Convolvulus L.

34. Convolvulus obscurus L., Sp. P1. ed. 2: 220.1762 [cited in Nat. Hist. II(7): Aanwyz. Plaat. [2], 539, tab. 42, fig. 1. 1777].

= Ipomoea obscura (L.) Ker Gawl. in Bot. Reg.: tab. 239. 1817.

Notes. - A specimen sent by Radermacher is mentioned by Houttuyn and is in G-PREL [G00818039]. There seems to be no corresponding specimen in UPS-THUNB.

35. Corchorus japonicus Thunb. ex Houtt., Nat. Hist. II(9): Aanwyz. Plaat. [1], 146, tab. 44, fig. 2. 1778.

Lectotypus (designated here by Veldkamp \& Callmander): JAPAN: Thunberg s.n. (G-PREL [G00818040]!; isolecto- : UPS-THUNB n $\left.{ }^{\circ} 12736 !\right)$.

$=$ Kerria japonica $($ L.) DC. in Trans. Linn. Soc. London $12: 157.1818$

Notes. - A single collection of original material has been located in the Japan herbarium in G-PREL. It is designated here as the lectotype of Corchorus japonicus.
36. Crinita capensis Houtt., Nat. Hist. II(7): Aanwyz. Plaat. [1], 362, tab. 40, fig. 1. 1777.

$\equiv$ Pavetta capensis (Houtt.) Bremek. in Repert. Spec. Nov. Regni Veg. 37: 166. 1934.

Lectotypus (designated here by Veldkamp) : SouTH AFrica: Cape, Auge s.n. [?] (G-PREL [G00818041]!).

Notes. - A single element of original material is in the Cape herbarium in G-PREL. This specimen is designated here as the lectotype.

37. Crinum angustifolium Houtt., Nat. Hist. II(12): Aanwyz. Plaat. [2], 165, tab. 81, fig. 3. 1780.

Lectotypus (designated here by Callmander): INDONESIA. Java: Anon. s.n. (G-PREL [G00818104]!) (Fig. 3).

$=$ Polianthes tuberosa L., Sp. P1.: 316. 1753.

Notes. - A single element of original material is in the Java herbarium in G-PREL. This collection is a good match for the plate and is designated here as the lectotype (Fig. 3).

38. Cyperus javanicus Houtt., Nat. Hist. II(13): Aanwyz. Plaat. [1], 67, tab. 88, fig. 1. 1782.

Lectotypus (designated here by Veldkamp): INDONESIA. Java: Anon. s.n. (G-PREL [G00360105]!).

Notes. - A single element of original material is in the Java herbarium in G-PREL. This collection is a good match for the plate and is designated here as the lectotype.

39. Dillenia indica L., Sp. P1.: 535. 1753 [cited in Nat. Hist. II(3): 60. 1774].

Notes. - A specimen is present in L (L-902.111-125) from the Ceylon herbarium, which was not available to Houttyun before 1778. There is another sheet in $\mathrm{L}$ of this from the Burman herbarium from "Zeylan" (L-902.111-121), annotated "Boo kerre", presumably a Sinhalese vernacular name.

40. Diosma pulchella sensu Houtt., Nat. Hist. II(4): Aanwyz. Plaat. [3], 326, tab. 21, fig. 2, 1775 [non D. pulchella L.].

= Diosma ovata Thunb., Prodr. P1. Cap. 1: 43. 1794. $\equiv$ Agathosma ovata (Thunb.) Pillans in J. S. African Bot. 16: 69. 1950. Lectotypus (designated by STRID, 1972: 42): SoUTH AFRICA: Cape, Thunberg s.n. (UPS-THUNB $\mathrm{n}^{\circ} 5700$ image seen; isolecto-: G-PREL [G00818115]!). 
Notes. - A specimen present in the Cape herbarium in G-PREL [G00818106]) is a good match for the plate. A Thunberg collection in the Burman herbarium represents an isolectotype of Diosma ovata (G-PREL [G00818115]).

\section{Echium capitatum L., Mant. P1. 1: 42.1767.}

$\equiv$ Lobostemon capitatus (L.) H. Buek in Linnaea 11: 143. 1837.

Notes. - A specimen from the Cape herbarium is in G-PREL [G00818042]. See Nordenstam \& Buys (2011) for more information on the accepted name.

42. Erica pulchella Houtt., Nat. Hist. II(4): Aanwyz. Plaat. [4], 504, tab. 23, fig. 1. 1775.

Lectotypus (designated here by Callmander): SouTH AfricA: Cape, Auge s.n. [?] (G-PREL [G00818128]!).

Notes. - Original material is in the Cape herbarium in G-PREL. The only collection there is a good match for the plate and is therefore designated here as the lectotype.

43. Erica splendida Houtt., Nat. Hist. II(4) : Aanwyz. Plaat. [4], 519, tab. 23, fig. 3. 1775.

Lectotypus (designated here by Callmander): SouTH AfricA: Cape, Auge s.n. [?] (G-PREL [G00818127]!) (Fig. 6).

Notes. - Original material is in the Cape herbarium in G-PREL. The only collection there is a good match for the plate and is therefore designated here as the lectotype (Fig. 6).

44. Erigeron capensis Houtt., Nat. Hist. II(10) : Aanwyz. Plaat. [4], 629, tab. 69, fig. 2. 1779.

$\equiv$ Hilliardiella capensis (Houtt.) H. Rob. et al. in PhytoKeys 60: 87.2016.

Lectotypus (designated here by Callmander): SouTH AfricA: Cape, Auge s.n. [?] (G-PREL [G00818097]!).

Notes. - Original material is in the Cape herbarium in G-PREL. The only collection there is a good match for the plate and is designated here as the lectotype.
45. Ethulia paniculata Houtt., Nat. Hist. II(10): Aanwyz. Plaat. [3], 551, tab. 67, fig. 2. 1779.

Lectotypus (designated here by Callmander): INDONESIA. Java: Anon. s.n. (G-PREL [G00818113]!).

= Dichrocephala integrifolia (L. f.) Kuntze, Revis. Gen. P1. 1:333. 1891.

Notes. - Original material is present in the Java herbarium in G-PREL. The single collection with Houttuyn's handwriting is designated here as the lectotype. It is a good match for the plate. Dichrocephala paniculata Miq. prevents the transfer of the earlier Houttuyn binomial to Dichrocephala L'Hér. ex DC. Another collection in the Houttuyn herbarium (G-PREL [G00818116]), cited under the name Spilanthes atriplicifolius (L.) L. in the Natuurlijke Historie (Nat. Hist. II(10): 536. 1779), also represents $D$. integrifolia.

46. Geranium chelidonium Houtt., Nat. Hist. II(10): Aanwyz. Plaat. [1], 8, tab. 61. 1779.

$\equiv$ Pelargonium chelidonium (Houtt.) DC., Prodr. 1: 650 . 1824.

Lectotypus (designated here by Veldkamp \& Callmander): South AfricA : Cape, Auge s.n. [?] (G-PREL [G00818043]!; isolecto-: G-DC [G00213107]!).

Notes. - The single collection in the Cape herbarium in G-PREL is designated here as the lectotype. A fragment of this collection is in the G-DC herbarium. No matching specimen is present in UPS-THUNB. Pelargonium ficaria Willd. (Willdenow, 1800: 643) is a superfluous name. No specimen has been found in the Willdenow herbarium (B-W).

47. Geranium ovale Burm. f., Fl. Ind. (Prodr. Fl. Cap.) : 19. 1768.

$\equiv$ Pelargonium ovale (Burm. f.) L'Hér. in Aiton, Hort. Kew. 2: 429.1789.

Lectotypus (designated by vAN DER WALT \& VAN ZUYL, 1988: 150): South AFricA: Cape, Auge s.n. [?] (G-PREL [G00818133]!).

Notes. - There is a specimen in Houttuyn's Cape herbarium [G00818133]. VAN DER WALT \& VAN ZuYL (1988: 150) designated a "specimen with Burman handwriting" as the lectotype but clearly failed to recognise Houttuyn's handwriting. This specimen, probably collected by Auge, should be considered in the lectotypification of Burman's name as it may have been available to Burman f. and collected by Auge. 


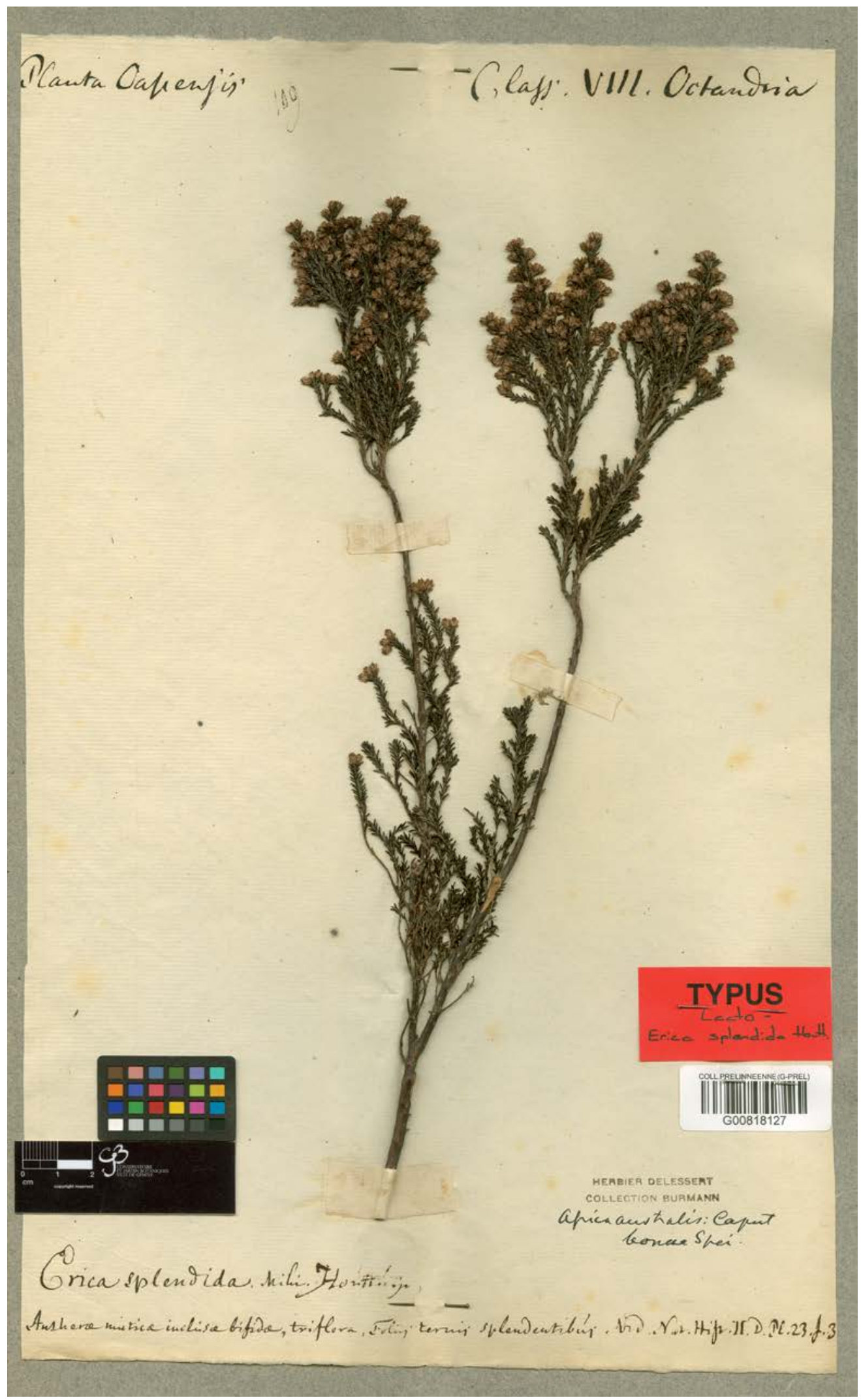

Fig. 6. - Lectotype of Erica splendida Houtt. in Houttuyn's Cape herbarium in G-PREL. 
48. Geranium tetragonum L. f., Suppl. P1.: 305. 1782.

$\equiv$ Pelargonium tetragonum (L. f.) L'Hér. in Aiton, Hort. Kew. 2: 427. 1789.

- Geranium quadrangulare Thunb. [nom. nud.].

Lectotypus (designated by Albers et al., 1995 : 344) : SOUTH AFRICA: Thunberg s.n. (UPS-THUNB n 15663 !; isolecto-: G-PREL [G00818045, G00818046, G00818047, G00818048]!, UPS-THUNB n 15662 image seen).

Notes. - Geranium tetragonum was based on a Thunberg specimen from the Cape. Albers et al. (1995: 344) designated a specimen in UPS-THUNB as the lectotype. Four duplicates of this collection are also present in G-PREL: three in the Burman herbarium [G00818045, G00818046, G00818047] and one in the Houttuyn herbarium [G00818048]. The latter bears the name G. quadrangulare Thunb. in Houttuyn's handwriting. The four G-PREL collections are duplicates of the original material and are here considered as isolectotypes.

49. Gladiolus liliaceus Houtt., Nat. Hist. II(12): Aanwyz. Plaat. [1], 55, tab. 79, fig. 2. 1780.

Lectotypus (designated here by Callmander): SouTH AFrICA: Cape, Auge s.n. [?] (G-PREL [G00818054]!).

Notes. - A single element of original material is in the Cape herbarium in G-PREL. This collection is designated here as the lectotype.

50. Gnaphalium aureum Thunb. ex Houtt., Nat. Hist. II(10): Aanwyz. Plaat. [3], 590, tab. 67, fig. 3. 1779.

$\equiv$ Helichrysum aureum (Thunb. ex Houtt.) Merr. in J. Arnold Arbor. 19: 372. 1938.

Lectotypus (designated by Hilliard \& Burtt, 1981: 239): South Africa: Cape, Thunberg s.n. (G-PREL [G00818049]!; probable isolecto-: G-PREL [G00818141]!) (Fig. 7).

Notes. - A specimen in the Cape herbarium in G-PREL (Fig. 7) was designated as the implicit lectotype by Hilliard \& Burtt (1981: 239) as "herb. Houttuyn now in herb. Burman, G!". A further specimen collected by Thunberg is in the Burman herbarium (G-PREL [G00818141]) and probably is an isolectotype. No duplicate has been located at UPS-THUNB.
51. Guilandina moringa L., Sp. P1.: 381. 1753. [cited in Nat. Hist. II(2) : 388. 1774].

$\equiv$ Moringa oleifera Lam., Encycl. 1:398.1785.

Notes. - A specimen in the Houttuyn herbarium from either Java or Ceylon is in G-PREL [G00818132].

A specimen from Java of this widespread SE Asian species is also present in L (L-908.133-1291). No corresponding specimen was found in UPS-THUNB. Another specimen from the Burman herbarium represents possible original material of Guilandina moringa, namely Burman 18 (G-PREL [G00818136]), which represents original material of the pre-Linnaean "Moringa zeylanica Burm." published in Thes. Zeyl.: 162, tab. 75. 1736. The Burman publication was cited by Linnaeus in 1753 and Burman 18 was designated as the lectotype by VIDAL (1962: 5), but rejected by the LinNaEAN Plant Name Typification Project (2016), indicating “... this would not have been studied by Linnaeus and is not original material". The correct lectotype, which Linnaeus definitely saw, was designated by Keraudren \& Gillett (1963:317): Hermann 2: 24, nْ 155 [BM000594587].

52. Hedysarum motorium Houtt., Nat. Hist. II(10): 246.1779.

$\equiv$ Codariocalyx motorius (Houtt.) Ohashi in J. Jap. Bot. 40: 367. 1965.

Typus: [INDONESIA. Java]: [cultivated in Leiden], D. van Royen s.n. (holo-: L-908.115-344!).

Notes. - Ohashi (2004: 109) mentioned a D. van Royen s.n. specimen in L (L-908.115-344) as the type of Hedysarum motorium. Houttuyn cited "a very small plant in the Hortus here", i.e. in the Botanical Garden of Amsterdam.

53. Hedysarum vaginale L., Sp. P1.: 746. 1753 [cited in Nat. Hist. II(10): 233. 1779].

$\equiv$ Alysicarpus vaginalis (L.) DC., Prodr. 2: 353. 1825.

Notes. - A specimen from the Ceylon herbarium is in G-PREL [G00818050] and there is another one in the Java herbarium (G-PREL [G00818051]).

54. Illecebrum lanatum (L.) L., Syst. Veg. ed. 13 : 206.1774 [cited in Nat. Hist. II(7): Aanwyz. Plaat. [2], 708, tab. 43, fig. 2.1777].

$\equiv$ Aerva lanata (L.) Juss. ex Schult. in Roem. \& Schult., Syst. Veg. ed. 15 bis, 5: 564. 1819. 




Fig. 7. - Lectotype of Gnaphalium aureum Thunb. ex Houtt. in Houttuyn's Cape herbarium in G-PREL. 
Notes. - Linnaeus (1771: 344) based Illecebrum lanatum on Achyranthes lanata L. (Linnaeus, 1753 : 204). Iamonico (2014: 407) erroneously lectotypified it with "Amaranthus spicatus zeylanicus, foliis obtusis" (Burman, 1737, vol. 1: tab. 26, fig. 1), which in fact depicts material of $A$. sicula (L.) All.

Two specimens in the Ceylon Herbarium were annotated by Houttuyn and Thunberg as Achyranthes lanata (G-PREL [G00818010, G00818011]). Another specimen is in L (L-902.283-2). Specimens from Ceylon and Java are in the Thunberg herbarium (UPS-THUNB n 5986 and $n^{\circ}$ 5987).

55. Ipomoea pilosa Houtt., Nat. Hist. II(7) : Aanwyz. Plaat. [2], 573, tab. 42, fig. 2.1777.

Lectotypus (designated here by Veldkamp): INDONESIA. Java: Radermacher s.n. [?] (G-PREL [G00818052]!).

$=$ Merremia umbellata (L.) Hallier. f. in Bot. Jahrb. Syst. $16: 552.1893$.

Notes. - The single specimen of original material in the Java herbarium in G-PREL is designated here as the lectotype. It was sent to Houttuyn by either Radermacher or Thunberg. No specimen is present in UPS-THUNB, where Hallier $f$. identified the material of Convolvulaceae.

56. Ixia campanulata Houtt., Nat. Hist. II(12): Aanwyz. Plaat. [1], 42, tab. 78, fig. 4. 1780.

Lectotypus (designated by Brown, 1929: 1933): SouTH AfricA: Cape, Auge s.n. [?] (G-PREL [G00818053]!).

$=$ Ixia aristata Thunb., Diss. Ixia: 14. 1783. $\equiv$ Ixia leucantha var. aristata (Thunb.) Baker, Hand. Irid.: 162. 1892. Lectotypus (designated here by Callmander \& Veldkamp): South AfricA: Cape, Thunberg s.n. (UPS-THUNB n 918 image seen).

Notes. - The type specimen of Ixia campanulata is in the Cape herbarium in G-PREL. MERRILL (1938: 327) did not recognise it as Houttuyn's. Brown (1929: 133) and Lewis (1962: 126) recognised this collection as the holotype, whereas GoLdBLATT \& Manning (2016: 185) correctly accepted Brown's mention as an implicit lectotypification. Four collections of possibly different gatherings are present in UPS-THUNB for Ixia aristata (UPSTHUNB $n^{\circ} 917, n^{\circ} 918, n^{\circ} 919$ and $\left.n^{\circ} 920\right)$. The better-preserved specimen is designated here as the lectotype.

Several other collections of Ixia L. are in Houttuyn's Cape herbarium: I. maculata L. (G-PREL [G008181221]), I. monadelpha D. Delaroche (G-PREL [G008181217, G008181218]), I. polystachya L. (G-PREL [G008181219]), and I. scillaris L. (G-PREL [G00818120]). Two further specimens identified by
Houttuyn as I. grandiflora D. Delaroche are now recognised in Sparaxis Ker Gawl. as S. grandiflora (D. Delaroche) Ker Gawl. (G-PREL [G00818122, G00818123]).

57. Lilium japonicum Thunb. ex Houtt., Nat. Hist. II(12) : Aanwyz. Plaat. [2], 245, tab. 82, fig. 2. 1780.

Lectotypus (designated here by Callmander \&Wijnands) : JAPAN: Thunberg s.n. (G-PREL [G00818143]!; isolecto- : UPS-THUNB n 8137 image seen).

Notes. - Original material is in the Japan herbarium in G-PREL. The single collection there is designated here as the lectotype. A duplicate is present in UPS-THUNB.

58. Lotus capensis Houtt., Nat. Hist. II(10): 311, tab. 65, fig. 3. 1779 .

Lectotypus (designated here by Callmander): SouTH AfricA: Cape, Auge s.n. [?] (G-PREL [G00818107]!).

$=$ Lotononis umbellata (L.) Benth. in London J. Bot. 2: 602.1843.

Notes. - Lotus capensis was considered to be a synonym of Lotononis umbellata by MERRILL (1938: 347). The former was not cited by VAN WYK (1991) in his revision of Lotononis (DC.) Eckl. \& Zeyh. A note by R. Dahlgren (Lund, 15.I.1959) on the Cape herbarium collection confirms that Houttuyn's species belongs to Lotononis. Lotus suffruticosus Burm. f. (Burman f., 1768: 22) undoubtedly represents the same taxon. Houttuyn cited Burman's binomial in Nat. Hist. II(10): Aanwyz. Plaat. [2]. 1779. No type specimen of the latter has been located in G-PREL but a fragment is present in G-DC [G00477415].

59. Massonia depressa Houtt., Nat. Hist. II(12): Aanwyz. Plaat. [3], 424, tab. 85, fig. 1. 1780.

Lectotypus (designated by Jessop, 1976: 411) : (Houttuyn, Nat. Hist. II(12) : tab. 85, fig. 1. 1780).

Epitypus (designated here by Callmander \& Veldkamp): SoUTH AFricA : Cape, Thunberg s.n. (UPS-THUNB $\mathrm{n}^{\circ} 7991$ image seen).

Notes. - The genus Massonia Thunb. ex Houtt. was described by Houttuyn in Natuurlijke Historie (Nat. Hist. II(12): 424.1780), with $M$. depressa listed as the only species. The description was based on "A Cape plant recently from the Hortus medicus of this place [Amsterdam] thus named by $\mathrm{Mr}$. Thunberg". The illustration shows two flowers, which were given to him by its Curator Johannes Storm in 1779 . Thunberg was paid by the Hortus for sending seeds and bulbs. No specimen 
of Massonia has been found in the Houttuyn herbarium in G-PREL. The illustration by Houttuyn must therefore be considered to be the type.

Massonia Thunb. ex L. f. (Linnaeus f., IV.1782: 27, 193) and Massonia Thunb. (Thunberg, 10.VII.1782:39) are later homonyms.

Massonia latifolia L. f. (and Thunb.) is based on a Masson collection that has never been located (LinNaEus f., 1782: 193; Thunberg, 1782: 40; see Jessop, 1976: 410-412). This species is now widely considered to be a synonym of the earlier M. depressa. Jessop (1976: 411) only found fruiting material at UPS-THUNB and implicitly designated Houttuyn's plate of flowers as the lectotype. A Thunberg flowering collection in UPS-THUNB, located by M. Hjertson (UPS), is designated here as the epitype.

60. Memecylon capitellatum L., Sp. P1.: 349. 1753 [cited in Nat. Hist. II(2): 300. 1774].

Notes. - A specimen is present in Houttuyn's Ceylon herbarium in G-PREL [G00818093]. There is no obvious corresponding collection in UPS-THUNB.

61. Memecylon floribundum Blume in Mus. Bot. 1: 361. 1851.

$=$ Memecylon caeruleum Jack in Malayan Misc. 1(5): 26. 1820.

Notes. - A specimen in the Java herbarium is in $\mathrm{L}$ (L-908.352-540), annotated "Tamba bisa" (see Bakhuizen van Den Brink, 1943: 359), Malay, perhaps meaning "possibly a Syzygium". There appears to be no Java specimen in UPS-THUNB.

62. Menispermum glabrum sensu Houtt., Nat. Hist. II(11): Aanwyz. Plaat. [3], 377, tab. 75, fig. 2. 1779 [non M. glabrum Burm.f.].

$=$ Stephania japonica var. discolor (Blume) Forman in Kew Bull. 11: 56. 1956.

Notes. - A specimen in the Java herbarium is in G-PREL [G00818094]. Diels identified it as Stephania hernandifolia (Willd.) Walp. Forman (1956: 51) cited this collection as $S$. japonica var. discolor. It is rather fragmentary and based on spirit material, and hardly matches the plate, in particular by the total absence of fruits. A specimen in the Thunberg herbarium (UPS-THUNB n ${ }^{\circ} 23658$ ) is probably a duplicate.
The holotype of Menispermum glabrum Burm. f. is Pryon s.n. (G-PREL [G00818095]) and represents material of Tinospora glabra (Burm. f.) Merr. A specimen without provenance is identified under that name in the Thunberg herbarium (UPSTHUNB n 23657).

63. Mussaenda frondosa L., Sp. P1.: 177. 1753 [cited in Nat. Hist. II(4): 226. 1775].

Notes. - A specimen in the Ceylon herbarium is in G-PREL [G00818055]; another is in the Thunberg herbarium (UPSTHUNB n ${ }^{\circ}$ 5000).

\section{Myristica fragrans Houtt., Nat. Hist. II(3): 333. 1774.}

Lectotypus (designated here by Callmander \& Veldkamp): INDONESIA. Moluccas: Anon. s.n. (G-PREL [G00818072]!) (Fig. 8).

Notes. - Warburg (1897: 472) cited a Houttuyn collection in the Vahl herbarium (C [C10015464]) in a list of specimens seen: "Houttuyn, Kopenhag, ster. Wein". Merrill (1938: 342) mentioned the same specimen annotated as "Myristica aromatica ded. Dr. Houttuyn”, whereas Sinclair (1968: 231) mentioned two Houttuyn collections at L and one in G as "Ex Herb. Burman". None of these publications designated a type for Myristica fragrans, the source of nutmeg.

One of the L sheets (L-908.133-1765) is annotated by Houttuyn with a reference to his publication (HoutTUYN, 1789b). The other was given to D. van Royen in 1784 (L-908.133-1797). Two collections have been located in Houttuyn's herbarium in G-PREL and are annotated by Houttuyn. The only collection with a reference to Houttuyn's Natuurlijke Historie is designated here as the lectotype. The remaining collections may be considered as part of original material.

De Wilde (2000: 470) designated a lectotype as: "J. W. Weinmann [Taalrijk Register 7 (1748) tab. 760-a]”. However, the presence of original material in Houttuyn's herbarium in G-PREL (Fig. 8) renders this lectotypification superfluous. The origin of the lectotype is quoted as Planta Ind. Orient. in Houttuyn's herbarium, referring to the Moluccas rather than Ceylon or Java, as is predominantly the case.

65. Nepeta incana Thunb. ex Houtt., Nat. Hist. II(9): Aanwyz. Plaat. [2], 306, tab. 56, fig. 2. 1778.

$\equiv$ Caryopteris incana (Thunb. ex Houtt.) Miq. in Ann. Mus. Bot. Lugduno-Batavi 2: 97.1866.

Lectotypus (designated here by Wijnands) : JAPAN : Thunberg s.n. (G-PREL [G00818056]!; isolecto- : UPSTHUNB n 13349 image seen). 


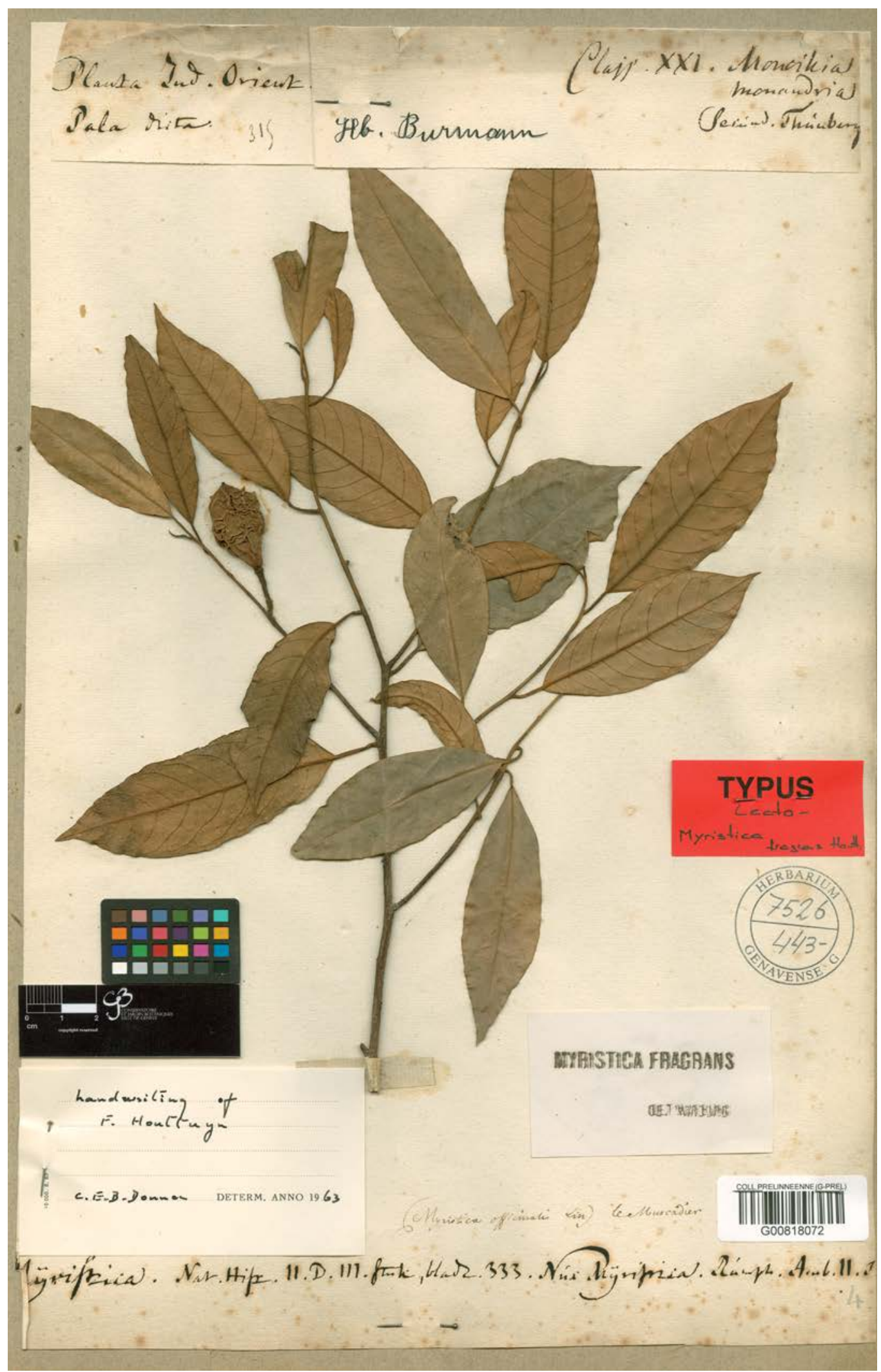

Fig. 8. - Lectotype of Myristica fragrans Houtt. in Houttuyn's herbarium in G-PREL. 
Notes. - Original material collected by Thunberg and present in the Japan herbarium is designated here as the lectotype. The same name [an isonym] was described by Thunberg using the UPS-THUNB material in Murray (1784: 529) and Thunberg (1784:244).

66. Nerium oleander L., Sp. P1.: 209. 1753 [cited in Nat. Hist. II(4): 389.1775].

Notes. - A specimen in the Java herbarium is in $\mathrm{L}$ (L-898.111-57). It represents material of Plumeria rubra L. (see Nat. Hist. II(2) : 178. 1774) (Fig. 2). Two leaves and an inflorescence are mounted with a mid-18th century pot, so far only known from this sheet (G. Thijsse, pers. comm. to the first author). Another specimen without provenance is present in the Thunberg herbarium (UPS-THUNB n ${ }^{\circ}$ 6128).

67. Nerium zeylanicum L., Cent. P1. 2: 12.1756 [cited in Nat. Hist. II(4) : 390. 1775].

$=$ Wrightia antidysenterica (L.) R. Br. in Mem. Wern. Nat. Hist. Soc. 1: 73.1811.

Notes. - A specimen in the Ceylon herbarium annotated by Thunberg as Nerium zeilanicum is in G-PREL [G00818057]. A Thunberg specimen from Ceylon is in the Thunberg herbarium (UPS-THUNB n ${ }^{\circ}$ 6125).

68. Ochna nitida sensu DC. in Ann. Mus. Natl. Hist. Nat. 17: 412. 1811 [non O. nitida Sw.].

= Ochna jabotapita L., Sp. Pl.: 513. 1753.

Notes. - Candolle $(1811,1824)$ identified and depicted a Thunberg collection from Ceylon in the Houttuyn herbarium ("v.s. in h. Deless.") as "Ochna nitida Thunb." He noted that the species came from "India orient.", but created confusion by citing "Thunb. prod. 67". The cited page of this work (Thunberg, 1794a) lists taxa of Hexandria, whereas Ochna L. belongs to the Polyandria monogynia, which are dealt with in the second volume (Thunberg, 1800: 92), although no Ochna are listed there. "Ochna nitida Thunb." is cited twice by Thunberg (1794b: 132; 1825: 7) as a nom. nud. (JueL, 1918: 251).

It is clear that de Candolle $(1811,1824)$ mistakenly cited Thunberg's Prodromus (1794a) when he actually intended to cite that of Swartz (1788). This is even more obvious from the description of the name, where de Candolle (1811: 412) wrote "calyci aequalia juxta Thunbergium", referring to Swartz (1788: 67): "calycibus corolla aeqvalibus".
Ochna nitida Sw. refers to a Roger Shakespear material from Jamaica, whereas de Candolle's misapplication of that name refers to a plant from Ceylon currently known as O. jabotapita L.

Kanis (1987: 248) designated a specimen in G-DC as the type of "Ochna nitida Thunb. ex DC." but this misapplied name has no nomenclatural status.

Material of Ochna jabotapita L. (= O. nitida sensu DC.) is present in the Thunberg herbarium (UPS-THUNB $\mathrm{n}^{\circ} 12528, \mathrm{n}^{\circ} 12539$ and $\mathrm{n}^{\circ} 12540$ ) and in G-DC [G00310780, G00310781]). The latter two sheets are from Houttuyn's herbarium but were originally in the Delessert herbarium, and were probably incorporated by de Candolle in his own herbarium, as no specimen has been located in G-PREL.

69. Ocimum sanctum L., Mant. P1. 1: 85.1767 [cited in Nat. Hist. II(9) : 422. 1778].

= Ocimum tenuiflorum L., Sp. P1.: 597.1753.

Notes. - A specimen in the Ceylon herbarium is in G-PREL [G00818058]. No Thunberg specimens from Java have been located in UPS-THUNB.

70. Oenanthe capensis Houtt., Nat. Hist. II(8): Aanwyz. Plaat. [1], 140, tab. 45, fig. 2. 1777.

Lectotypus (designated here by Veldkamp) : SouTH AFRICA: Auge s.n. [?] (G-PREL [G00818059]!).

= Bubon proliferum Burm. f., Fl. Ind. (Prodr. Fl. Cap.): 7.1768. $\equiv$ Glia prolifera (Burm. f.) B.L. Burtt in Edinburgh J. Bot. 48: 208. 1991. Lectotypus (designated here by Callmander): SouTH AFricA: Cape, Garcin 100 (G-PREL [G00818060]!).

Notes. - Original material of Oenanthe capensis probably collected by Auge is in the Cape herbarium in G-PREL. It is designated here as the lectotype.

Bubon proliferum was based on a Garcin collection in the Burman herbarium, which is designated here as the lectotype. Laurent Garcin (1683-1752), a VOC ship's surgeon originating from Nyon, a town not far from Geneva, provided collections to Burman, which were then used by his son for his Flora Indica and Prodromus Florae Capensis (Burman f., 1768) (see Wijnands, 1992; Соок, 2016).

71. Oldenlandia linearifolia Thunb., F1. Jav.: 9. 1825.

Typus: INDONESIA. Java : Thunberg s.n. (holo-: UPSTHUNB n 3655 image seen; iso-: G-DC [G00208560]!, G-PREL [G00818061]!). 
Notes. - Not discussed by Houttuyn, but a specimen is present in his Java herbarium in G-PREL [G00818061] from around Batavia ("Omstreeks Batavia"). This collection was annotated by Thunberg as $O$. linearifolia and should be considered as a duplicate of the holotype in the Thunberg herbarium (UPS-THUNB n ${ }^{\circ} 3655$ ).

Another specimen from Houttuyn's Java herbarium is in G-DC [G00208560] filed under O. brachypoda DC. (Candolle, 1830b: 424).

72. Ophioglossum acuminatum Houtt., Nat. Hist. II(14): Aanwyz. Plaat. [1], 49, tab. 94, fig. 3.1783.

Lectotypus (designated here by Veldkamp \& Callmander): INDONESIA.Java: Thunberg s.n. (G-PREL [G00818062]!).

$=$ Nephrolepis davallioides (Sw.) Kunze in Bot. Zeitung (Berlin) 4: 460. 1846.

Notes. - Hovenkamp \& Miyamoto (2005: 298) indicated that the type was the plate in Natuurlijke Historie, as follows: "Type: Plate in Houttuyn". A specimen of original material collected by Thunberg is in the Java herbarium with a label "van 't gebergte bezuiden Batavia" ["from the mountains south of Batavia"]. Houttuyn mentioned the same origin in Nat. Hist. II(14): 49.1783. The plate could well have been drawn from this specimen, now remounted, which is designated here as the lectotype.

73. Ophioglossum zeilanicum Houtt., Nat. Hist. II(14): Aanwyz. Plaat. [1], 43, tab. 94, fig. 1. 1783.

$\equiv$ Tectaria zeilanica (Houtt.) Sledge in Kew Bull. 27: 422.1972.

Lectotypus (designated here by Callmander \& Fumeaux): Ceylon [SRI LANKa] : Thunberg s.n. (G-PREL [G00818063]!; isolecto-: UPS-THUNB n 24418 image seen) (Fig. 9).

Notes. - Holt tum (1991: 75) designated a type specimen at UPS: "Type: Thunberg s.n., Sri Lanka (UPS, not seen)". The finding of a specimen annotated by Houttuyn in his own herbarium in G-PREL (Fig. 9) supersedes this implicit lectotypification. Houttuyn's plate was clearly drawn from the specimen in G-PREL.

On the latter sheet and in Aanwyz. Plaat., the epithet is spelled as the more usual "zeylanicum", but on p. 43 as "zeilanicum", which is the spelling that most people saw and copied and that should be retained. It was identified as Acrostichum quercifolium Retz. by H. Christ, a synonym according to HoLtTum (1991: 75).

Ophioglossum zeilanicum is the first report by Houttuyn of a specimen from Ceylon in his own herebarium (see introduction p. 160).
74. Ornithogalum dubium Houtt., Nat. Hist. II(12): Aanwyz. Plaat. [2], 309, tab. 82, fig. 3. 1780.

Lectotypus (designated here by Wijnands): SoUTH AFricA: Auge s.n. [?] (G-PREL [G00818064]!).

Notes. - Original material is present in the Cape herbarium. It is designated here as the lectotype. There is no obvious corresponding collection in UPS-THUNB.

75. Osmunda japonica Thunb. in Nova Acta Regiae Soc. Sci. Upsal. 3 : 209. 1780 [cited in Nat. Hist. II(14): Aanwyz. Plaat. [1], 57, tab. 95, fig. 1. 1783].

Lectotypus (designated by Nakaike in Katsuyama et al., 2013: 44): JAPAN: Thunberg s.n. (UPS-THUNB n 25200 image seen; isolecto- : G-PREL [G00818130]!, UPSTHUNB n 25199 image seen).

Notes. - Original material is present in the Japan herbarium in G-PREL. The single fertile collection at UPS-THUNB is designated here as the lectotype. Nakaike already annotated it as such in 1978 but the lectotypification was validated in 2013 in Katsuyama et al. (2013).

76. Osmunda japonica Houtt., Nat. Hist. II(14): Aanwyz. Plaat. [1], 57, tab. 95, fig. 1. 1783 [non O. japonica Thunb.].

$\equiv$ Osmunda lancea Thunb. in Murr., Syst. Veg. ed. 14: 928. 1784; F1. Jap.: 330. 1784. Lectotypus (designated by Nakaike in KatsuYama et al., 2013: 44): JAPAN : Thunberg s.n. (UPS-THUNB n 25201 image seen; iso- : G-PREL [G00818129]!).

Notes. - Osmunda japonica Houtt. is a later homonym of O. japonica Thunb. As Houttuyn cited O. lancea the name is also superfluous.

77. Oxalis sensitiva L., Sp. Pl.: 434.1753 [cited in Nat. Hist. $\mathrm{II}(8): 659.1777]$.

$\equiv$ Biophytum sensitivum (L.) DC., Prodr. 1: 690.1824.

Notes. - A specimen in the Java herbarium is in G-PREL [G00818065]. Another one is in the Thunberg herbarium (UPS-THUNB n 11121).

78. Paspalum dissectum (L.) L., Sp. P1. ed. 2: 81.1762 [cited in Nat. Hist. II(13): Aanwyz. Plaat. [1], 164, tab. 89, fig. 2. 1782].

$\equiv$ Panicum dissectum L., Sp. P1.: 57.1753. 




Fig. 9. - Lectotype of Ophioglossum zeilanicum Houtt. in Houttuyn's herbarium in G-PREL. 
Notes. - A collection probably from the Java herbarium is in L (L-904.26-22) (see van Steenis \& Veld Kamp, 1973: 151). The specimen on the left-hand of L-904.26-22 is the one depicted in Natuurlijke Historie. Another specimen from Java is in G-PREL [G00818066].

79. Phalangium spicatum Houtt., Nat. Hist. II(12): Aanwyz. Plaat. [2], 115, tab. 80, fig. 2. 1780.

Lectotypus (designated here by Callmander \& Fumeaux): SouTH AFricA: Auge s.n. [?] (G-PREL [G00818067]!).

= Micranthus plantagineus Eckl., Topogr. Verz. Pflanzensamml. Ecklon: 43.1827.

Notes. - The single element of original material in the Cape herbarium is designated here as the lectotype. It is a good match for the plate. Micranthus spicatus (L.) Heyn. prevents the transfer of Houttuyn's epithet to the genus Micranthus (Pers.) Eckl. See GoLDBLATT et al. (2013: 140-142) for an interesting discussion on $M$. plantagineus. The latter authors considered the plate in Nat. Hist. II(12): tab. 80, fig. 2.1780 to be the type of Houttuyn's name (i.e., they implicitly designated it as the lectotype), but the existence of original material supersedes their lectotypification.

80. Phleum indicum Houtt., Nat. Hist. II(13): Aanwyz. Plaat. [1], 198, tab. 90, fig. 2. 1782.

$\equiv$ Polytrias indica (Houtt.) Veldk. in Blumea 36: 180. 1991.

Lectotypus (designated here by Veldkamp): INDONESIA. Java: Anon. s.n. (G-PREL [G00096222]!).

Notes. - The original material designated here as the lectotype is in the Java herbarium in G-PREL. See Veldkamp (1991) for a discussion on this species.

81. Piper officinarum (Miq.) C. DC., Prodr. 16(1): 356. 1869.

$=$ Piper retrofractum Vahl, Enum. Pl. 1: 314.1804.

Notes. - Two specimens from Houttuyn's Java herbarium are respectively in G-PREL [G00818068] and G-DC [G00206609]. Both specimens are annotated as "Piper longum L." by Houttuyn. A possible duplicate in L (L-908.165-114) is also marked "Piper longum L. Cl. Houttuin dedit Jun 1784" (msc. D. van Royen).

82. Plumbago rosea L., Sp. Pl. ed. 2: 215.1762 [cited in Nat. Hist. II(7): 522. 1777].

$=$ Plumbago indica L., Amboin.: 24. 1754.
Notes. - A specimen in the Ceylon herbarium is in G-PREL [G00818069]. A corresponding specimen is in the Thunberg herbarium (UPS-THUNB $n^{\circ} 4373$ ).

83. Poinciana pulcherrima L., Sp. Pl. ed. 2:215. 1762 [cited in Nat. Hist. II(5): 42.1775].

$\equiv$ Caesalpinia pulcherrima (L.) Sw., Observ. Bot.: 166. 1791.

Notes. - A specimen from the Java herbarium is in L (L-913.64.595) mounted with a curious blue undecorated piece of paper, cut out in the shape of a small pot (Fig. 1).

84. Polygala japonica Houtt., Nat. Hist. II(10): Aanwyz. Plaat. [1], 89, tab. 62, fig. 1. 1779.

Lectotypus (designated here by Veldkamp \& Callmander): JAPAN: Thunberg s.n. (G-PREL [G00818070]!; isolecto-: G-PREL [G00818071]!) (Fig. 10).

Notes. - A specimen of original material collected by Thunberg has been located in the Japan herbarium in G-PREL. Thunberg annotated it as "Polygala vulgaris ? Lin." and Houttuyn as "Polygala vulgaris Linn. vel potius Japonica, mihi. Nat. Hist. X. Stuk p. 89, P1. 62. Fig. 1" with a later addendum “Thunb. Jap. p. 277". The specimen is a very good match for the plate and is designated here as the lectotype. A corresponding specimen seems to be absent from UPSTHUNB. Another Thunberg specimen is in the Burman herbarium in G-PREL [G00818071] and should be considered as a duplicate. There are Chinese and Japanese vernacular names at the bottom of the latter sheet which were not mentioned by Houttuyn and do not seem to be in his writing.

85. Polypodium japonicum Thunb. ex Houtt., Nat. Hist. II(14): Aanwyz. Plaat. [2], 167, tab. 98, fig. 3.1783.

Lectotypus (designated here by Wijnands) : JAPAN : Thunberg s.n. (G-PREL [G00818090]! ; isolecto- : UPSTHUNB n 24493 and $n^{\circ} 24494$ images seen).

= Polypodium falcatum Thunb. ex L. f., Suppl. P1.: 446. 1782. = Cyrtomium falcatum (Thunb. ex L. f.) C. Presl, Tent. Pterid.: 86. 1836. Lectotypus (designated here by Callmander): JAPAN: Thunberg s.n. (UPS-THUNB $n^{\circ} 24493$ image seen; isolecto-: G-PREL [G00818090]!, UPS-THUNB n 24494 image seen).

Notes. - A single element representing original material is in the Japan herbarium in G-PREL. It is a very good match for the plate and is designated here as the lectotype 


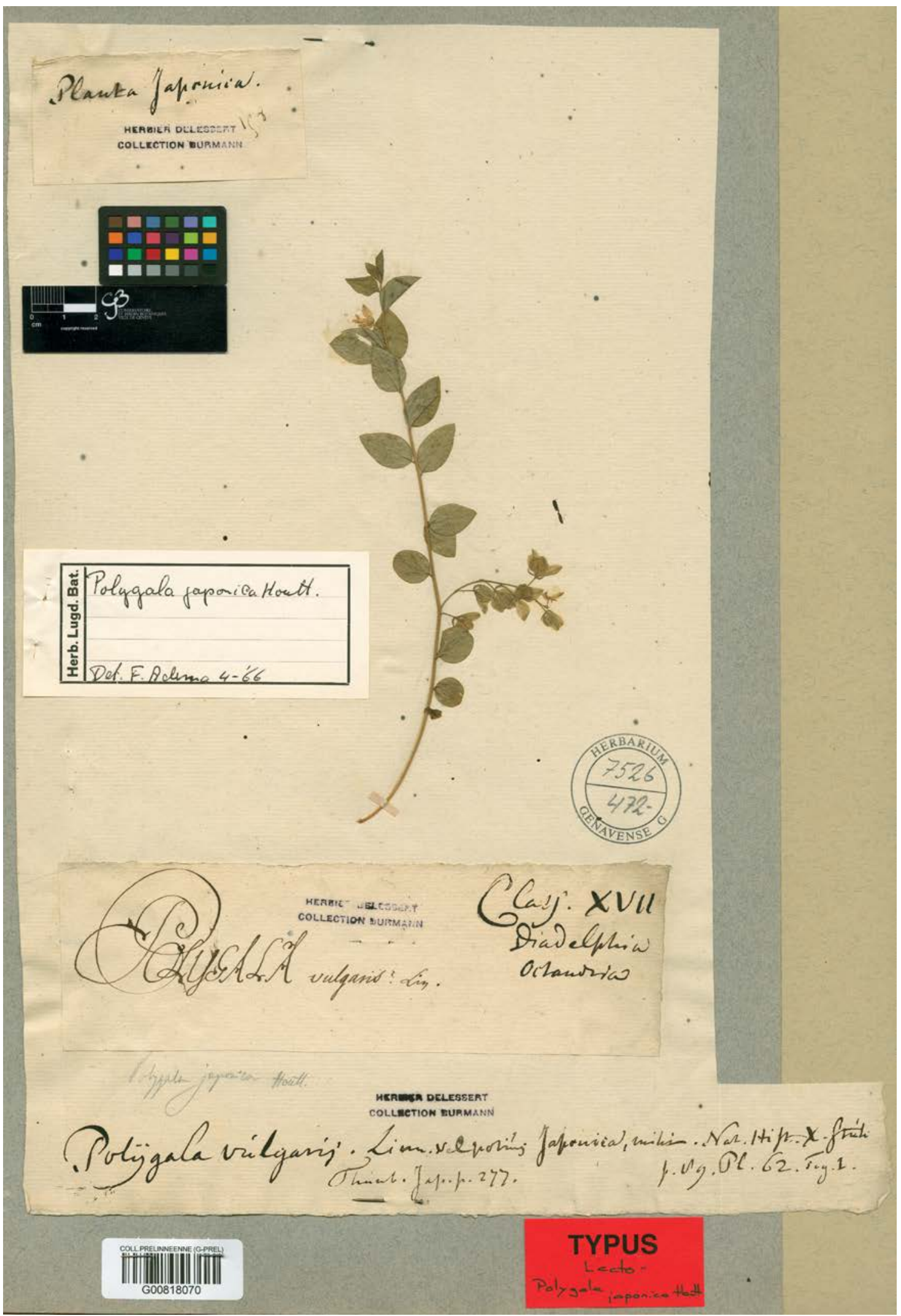

Fig. 10. - Lectotype of Polygala japonica Houtt. in Houttuyn's Japan herbarium in G-PREL. 
of Polypodium japonicum. Houttuyn annotated the specimen as "Polypodium japonicum Thunb. vel falcatum F1. Japon. p. 336, tab. 36", so he apparently compared his plant with a manuscript of Thunberg's work that was published in 1784, after the publication in the Natuurlijke Historie had been completed. He did not cite Linnaeus f. (1782) where P. falcatum Thunb. ex L. f. was published, based on the same duplicates in the Thunberg herbarium. Two collections of original material are present in UPS-THUNB. The lectotype of $P$. falcatum designated here is the most complete sheet (UPS-THUNB n² 24493).

86. Polypodium pedatum Houtt., Nat. Hist. II(14): Aanwyz. Plaat. [2], 148, tab. 98, fig. 1.1783.

Lectotypus (designated here by Callmander): JAPAN : Thunberg s.n. (G-PREL [G00349561]!; isolecto- : UPSTHUNB n ${ }^{\circ} 25244, n^{\circ} 25245$ and n 25247 images seen).

= Polypodium lineare Burm. f., Fl. Indica: 235, tab. 67, fig. 2. 1768. $\equiv$ Dicranopteris linearis (Burm. f.) Underw. in Bull. Torrey Bot. Club 34: 250. 1907. Lectotypus (designated by Schelpe \& ANTHony 1986: 49): INDONESIA.Java: van Santen s.n. (G-PREL [G00360111]!).

$=$ Polypodium dichotomum Thunb. in Murr., Syst. Veg. ed. 14: 512. V-VI.1784. Lectotypus (designated here by Callmander) : JAPAN: Thunberg s.n. (UPS-THUNB n 25247 image seen; isolecto-: G-PREL [G00349561]!, UPS-THUNB $n^{\circ} 25244$ and $n^{\circ} 25245$ images seen).

Notes. - The original material of Polypodium pedatum is in the Japan herbarium in G-PREL. This collection is a very good match for the plate and is designated here as the lectotype. Thunberg in Murray (1784: 512) described P. dichotomum based on the same Thunberg collection in his herbarium. This name is also cited in Thunberg (1784: 338, tab. 37).

87. Polypodium trilobum Houtt., Nat. Hist. II(14) : Aanwyz. Plaat. [2], 148, tab. 98, fig. 1.1783.

$\equiv$ Selliguea triloba (Houtt.) M.G. Price in Blumea 43: 57. 1998.

Lectotypus (designated here by Callmander \& Fumeaux): INDONESIA.Java: Thunberg s.n. (G-PREL [G00818150]!).

Notes. - A single collection of original material is in the Java herbarium in G-PREL. This collection is a very good match for the plate and is designated here as the lectotype.
88. Prenanthes denticulata Houtt., Nat. Hist. II(10): Aanwyz. Plaat. [3], 385, tab. 66, fig. 4. 1779.

$\equiv$ Crepidiastrum denticulatum (Houtt.) Pak \& Kawano in Mem. Fac. Sci. Kyoto Univ., Ser. Biol. 15 : 56. 1992.

Lectotypus (designated here by Callmander): JAPAN : Thunberg s.n. (G-PREL [G00818096]! ; isolecto-: UPSTHUNB n 18119 image seen).

Notes. - The specimen collected by Thunberg in the Japan herbarium in G-PREL is designated here as the lectotype. It is a good match for the plate.

89. Prenanthes laciniata Houtt., Nat. Hist. II(10): Aanwyz. Plaat. [3], 381, tab. 66, fig. 1.1779.

Lectotypus (designated here by Callmander): JAPAN : Thunberg s.n. (G-PREL [G00818100]!; isolecto-: UPSTHUNB n 18135 image seen).

$=$ Lactuca indica L., Mant. P1. 2: 278. 1771.

Notes. - The only element of original material in the Japan herbarium in G-PREL collected by Thunberg is designated here as the lectotype. It is a good match for the plate. A duplicate is present in UPS-THUNB.

90. Prenanthes lanceolata Houtt., Nat. Hist. II(10) : Aanwyz. Plaat. [3], 383, tab. 66, fig. 2. 1779.

$\equiv$ Crepidiastrum lanceolatum (Houtt.) Nakai in Bot. Mag. (Tokyo) 34:150. 1920.

Lectotypus (designated here by Callmander): JAPAN : Thunberg s.n. (G-PREL [G00818099]! ; isolecto-: UPSTHUNB n 18121 image seen).

Notes. - Original material collected by Thunberg is in the Japan herbarium in G-PREL. It is a good match for the plate and is designated here as the lectotype.

91. Protea linearis Houtt., Nat. Hist. II(4) : Aanwyz. Plaat. [1], 116, tab. 19, fig. 2. 1775.

Lectotypus (designated here by Veldkamp \& Callmander): South AFRICA: Cape, Auge s.n. [?] (G-PREL [G00818074]!).

$=$ Leucadendron brunioides Meisn. in A. DC., Prodr. 14: 215. 1856.

Notes. - A single original specimen is in the Cape herbarium in G-PREL probably collected by Auge. This collection was used for the illustration and is designated here as the lectotype. 
Protea linearis is the first report by Houttuyn of a specimen from South Africa in his own herbarium (see introduction p. 158).

92. Pteris orbiculata Houtt., Nat. Hist. II(14): Aanwyz. Plaat. [1], 108, tab. 96, fig. 3. 1783.

Lectotypus (designated here by Callmander): SouTH AfricA: Cape, Auge s.n. [?] (G-PREL [G00818088]!).

Notes. - The single specimen representing original material is in the Cape herbarium in G-PREL. It is designated here as the lectotype.

93. Radermachia integra Thunb., Kongl. Vetensk. Acad. Handl. $37: 254.1776$.

$\equiv$ Artocarpus integra (Thunb.) Merr., Interpr. Herb. Amboin.: 190. 1917.

Lectotypus (designated by Corner, 1939: 70): INDONESIA. Java: Thunberg s.n. (UPS-THUNB 21664 [parts a and b] image seen; isolecto- : G-PREL [G00818144]!, L-908.185-852!, L-908.185-883!).

Notes. - The genus Radermachia Thunb. published by Thunberg $(1776: 251)$ is now accepted under the name Artocarpus J.R. Forst. \& G. Forst. Radermachia was published with no type species designated and the lectotype is designated here by Veldkamp: Radermachia incisa Thunb. (=Artocarpus altilis (Parkinson) Fosberg). Original material of Radermachia incisa is in Houttuyn's Java herbarium in G-PREL [G00818146].

Two duplicates of $R$. integra are present in $\mathrm{L}$ in the Java herbarium (L-908.185-852 and L-908.185-883). The first one is annotated by Thunberg as "Radermachia integra Thunb." Both are labelled as isotypes by Jarrett (I.1956) and identified as Artocarpus integra. A duplicate is also present in Houttuyn's Java herbarium in G-PREL.

94. Rajania quinata Thunb. ex Houtt., Nat. Hist. II(11) : Aanwyz. Plaat. [3], 366, tab. 75, fig. 1.1779.

$\equiv$ Akebia quinata (Thunb. ex Houtt.) Decne. in Ann. Sci. Nat., Bot. sér. 2, 12: 107. 1839.

Lectotypus (designated here by Callmander \& Veldkamp): JAPAN : Thunberg s.n. (G-PREL [G00818075]!; isolecto- : G-PREL [G00818076, G00818077]!, UPSTHUNB n 23530 and $n^{\circ} 23531$ images seen).

Notes. - Decaisne (1839: 107) based his new combination on "Thunb. F1. Jap. p. 148”, which should be corrected to Thunberg in Murray (1784: 888), but this is still a later homonym of Houttuyn's name.

The original collection designated here as the lectotype is in the Japan herbarium, collected and annotated by Thunberg. It is not a very good match for the plate. On the same page Houttuyn mentioned Rajania quinquefolia, this name is written on the sheet as well. This is a West Indian species. Isolectotypes are present in the Houttuyn herbarium (G-PREL [G00818076]), the Burman herbarium (G-PREL [G00818077]), and the Thunberg herbarium (UPS-THUNB n 23530 and $n^{\circ} 23531$ ).

95. Renealmia capensis Houtt., Nat. Hist. II(8) : Aanwyz. Plaat. [2], 335, tab. 47, fig. 1. 1777.

$\equiv$ Villarsia capensis (Houtt.) Merr. in J. Arnold Arbor. 19: 360. 1938.

Lectotypus (designated here by Veldkamp \& Callmander) : SouTH AFricA: Cape, Thunberg s.n. (G-PREL [G00074336]! ; isolecto-: G-PREL [G00818091, G00818092]!, UPS-THUNB n 4228 image seen).

= Menyanthes capensis Thunb., Prodr. P1. Cap.: 34. 1794. Typus : SouTH AfricA: Cape, Thunberg s.n. (holo-: UPS-THUNB n 4228 image seen; iso-: G-PREL [G00074336, G00818091, G00818092]!).

Notes. - Original material of Renealmia capensis in Houttuyn's Cape herbarium is designated here as the lectotype. It was very likely collected by Thunberg and also represents a duplicate of the type of the later name Menyanthes capensis Thunb. Two further specimens in the Burman herbarium in G-PREL were annotated by Thunberg as Menyanthes capensis and represent original material of both Houttuyn's and Thunberg's names. Menyanthes ovata L.f. (Linnaeus f., 1782: 133) is also based on the same Thunberg collection at UPS-THUNB, but this name is superfluous, as well as the combination by VENTENAT (18031808: sub tab. 9): Villarsia ovata (L. f.) Vent. (CAllmander et al., 2017).

The generic Renealmia Houtt. was published by Houttuyn in 1777 (Nat. Hist. II(8) : 335). Houttuyn noted "A new genus ... which I ... baptise with the name now available". Up to the beginning of the 19th century botanists often regarded that a name placed in synonymy was then available for another use, a practice that is no longer allowed. The generic name Renealmia had previously been validated by Linnaeus (1753: 286). Both are nom. rej. [against the nom. cons. of Linnaeus f. (1782: 7)].

96. Reynoutria japonica Houtt., Nat. Hist. II(8): Aanwyz. Plaat. [3], 640, tab. 51, fig. 1. 1777.

$\equiv$ Fallopiajaponica (Houtt.) Ronse Decr. in Bot. J. Linn. Soc. 98: 369. 1988.

Lectotypus (designated here by Callmander) : JAPAN : Thunberg s.n. (G-PREL [G00818124]!) (Fig. 11). 


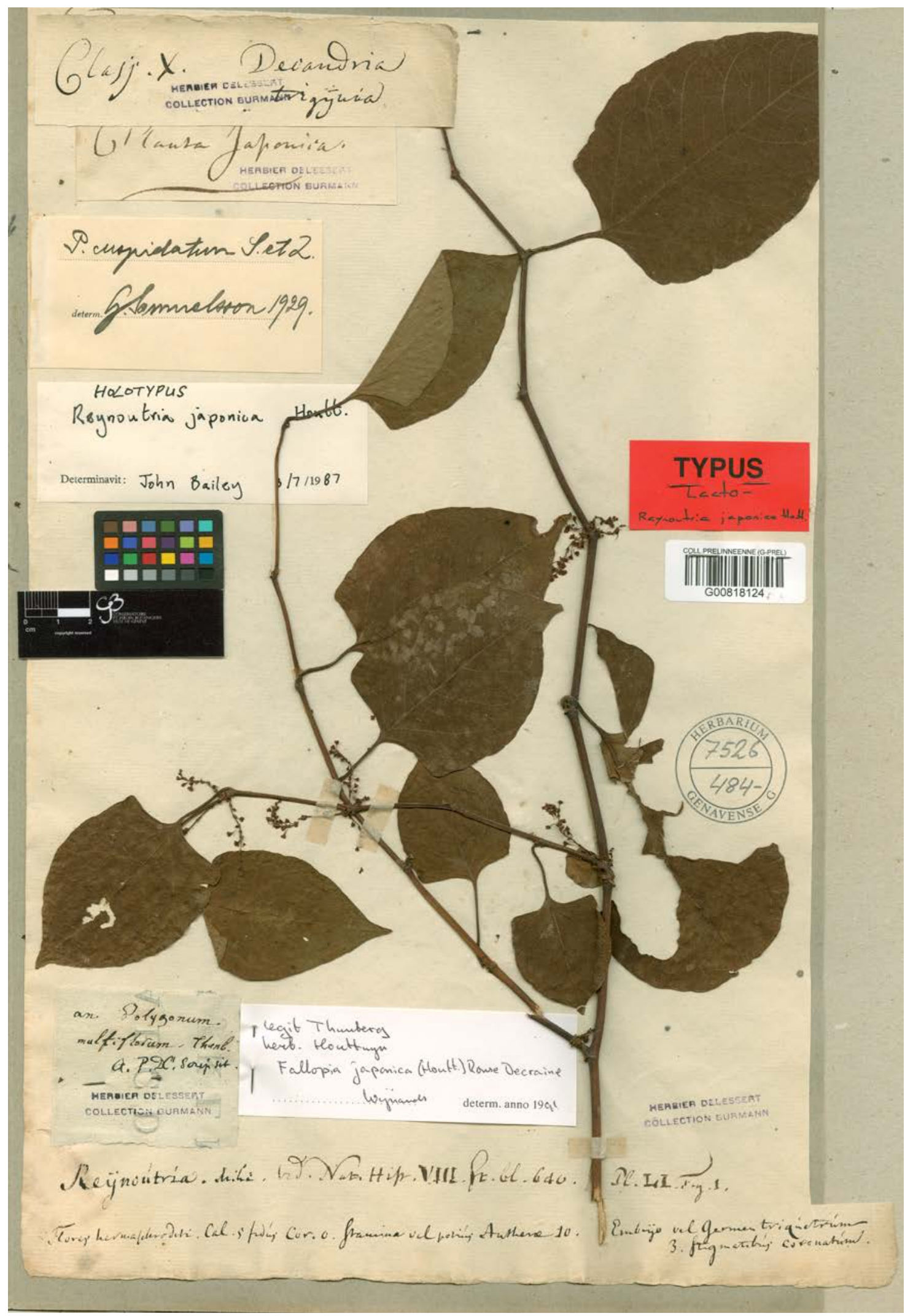

Fig. 11. - Lectotype of Reynoutria japonica Houtt. in Houttuyn's Japan herbarium in G-PREL. 
Notes. - The only specimen representing original material collected by Thunberg is in the Japan herbarium in G-PREL. It is designated here as the lectotype (Fig. 11). It is a good match for the plate.

97. Ruellia ringens sensu Houtt., Nat. Hist. II(9): Aanwyz. Plaat. [4], 577, tab. 59, fig. 2. 1778 [non $R$. ringens L.].

$=$ Ruellia erecta Burm. f., F1. Indica: 135, tab. 41, fig. 3. 1768. =Hygrophila erecta (Burm. f.) Hochr. in Candollea 5 : 230. 1934. Lectotypus (designated here by Callmander \& Fumeaux): IndiA: Anon. s.n. (G-PREL [G00818109]!).

$=$ Ruellia repens Burm. f., F1. Indica: 235, tab. 67, fig. 2 [err. typ. fig. 1]. 1768 [non $R$. repens L.]. Lectotypus (designated here by Fumeaux \& Callmander): INDONESIA.Java: Kleynhoff s.n. (G-PREL [G00818155]!).

Notes. - Hochreutiner (1934: 230) transferred Ruellia erecta to Hygrophyla R. Br. and explained that Ruellia repens Burm. f. [non $R$. repens L.] should be considered as a synonym of $H$. erecta. Two specimens with the handwriting of Burman $f$. are present in G-PREL, each of which is designated here as lectotypes: a Kleynhoff collection from Java [G00818155] and a second sheet from an anonymous collector [G00818109], determined by Burman $\mathrm{f}$. as $R$. erecta. Three collections exist in the Java herbarium annotated by Houttuyn, respectively, as "Ruellia erecta" [G00818108], "Ruellia repens Burm." [G00818111], and "Ruellia ringens L." [G00818110]. Thunberg collected the latter two, referring both to Hygrophila erecta.

98. Rumex japonicus Houtt., Nat. Hist. II(8): Aanwyz. Plaat. [2], 394, tab. 47, fig. 2. 1777.

Lectotypus (designated here by Wijnands):JAPAN: Thunberg s.n. (G-PREL [G00818079]!).

Notes. - The only specimen representing original material in the Japan herbarium is designated here as lectotype. It is annotated by Houttuyn as "Rumex dentatus L. ?" Houttuyn noted on the sheet that the fruit was drawn for Nat. Hist. II(8): tab. 47, fig. 2. No duplicate has been found in UPS-THUNB.

99. Rumex umbellatus Houtt., Nat. Hist. II(8) : Aanwyz. Plaat. [2], 414, tab. 47, fig. 3. 1777.

Lectotypus (designated here by Veldkamp) : JAPAN : Thunberg s.n. (G-PREL [G00818078]!).

$=$ Persicaria chinensis (L.) H. Gross in Bot. Jahrb. Syst. 49: 269.1913
Notes. - Original material is in the Japan herbarium in G-PREL. The only collection there is a good match for the plate and is therefore designated here as the lectotype. No duplicate has been found in UPS-THUNB.

100. Saccharum japonicum Houtt., Nat. Hist. II(13): Aanwyz. Plaat. [1], 146, tab. 89, fig. 1.1782.

$\equiv$ Miscanthus japonicus (Houtt.) Andersson in Öfvers. Kongl. Vetensk.-Akad. Förh. 12: 166. 1855.

Lectotypus (designated here by Veldkamp) : JAPAN : Thunberg s.n. (G-PREL [G00818080]!; isolecto- : UPSTHUNB n 1739 image seen; LE [Herb. Trinius 24.1] image seen).

Notes. - A specimen of original material is in the Japan herbarium in G-PREL annotated as "Saccharum aristatum vel biflorum". A duplicate in the Thunberg herbarium (UPSTHUNB n ${ }^{\circ} 1739$ ) is annotated as S.japonicum. This was originally identified by Thunberg (1794c: 329$)$ as $S$. polydactylon L. The duplicate in LE was used by Trinius (1820:169) for his combination Ripidium japonicum (Houtt.) Trin.

Merrill (1938: 320) corrected the basionym author of Miscanthus japonicus from Thunberg to Houttuyn as Thunberg's name is a later isonym.

101. Selago rapunculoides L., Cent. P1. II : 22. 1756 [cited in Nat. Hist. II(5): 324. 1775].

= Selago spuria L., Sp. P1.: 629. 1753.

Note. - A specimen in the Cape herbarium is in G-PREL [G00818081].

102. Sida cordifolia L., Sp. P1.: 684. 1753 [cited in Nat. Hist. II(10): 39. 1779].

Notes. - A specimen in the Java herbarium is in G-PREL [G00818082]. A specimen annotated as "S. rotundifolia" is in the Thunberg herbarium (UPS-THUNB $n^{\circ} 15869$ ), and another one is in L [L.0079191], annotated "Sida cordifolia. Linn." and with a brief description by Houttuyn. The collection UPS-THUNB n 15821 represents $S$. cordifolia, which was cultivated in the Uppsala Botanical Garden without provenance. 
103. Smilax zeylanica L., Sp. P1.: 1029. 1753 [cited in Nat. Hist. II(6): 356. 1776].

Note. - A specimen in the Ceylon herbarium is in G-PREL [G00818084].

104. Stipa littorea Burm. f., Fl. Indica: 29.1768 [cited under Stipa spinifex L. in Nat. Hist. II(13): Aanwyz. Plaat. [2], 335 ; also cited under Spinifex squarrosus L., in Nat. Hist. II(13): 561, tab. 92, fig. 2. 1782].

$\equiv$ Spinifex littoreus (Burm. f.) Merr. in Philipp. J. Sci. 7: 229. 1912.

Lectotypus (designated here by Wijnands, Veldkamp \& Callmander) : INDONESIA. Java : Anon. s.n. (G-PREL [G00360104]!).

Notes. - The only specimen of original material in the Burman herbarium is designated here as the lectotype. This collection is annotated as "rompot laut javanis" ["sea grass by the Javanese"] and represents a staminate plant. Houttuyn was clearly confused about this species, which he discussed twice, obviously unaware that it is dioecious. The single collection in his Ceylon herbarium [G00818158] also is a staminate plant of Spinifex littoreus.

105. Teucrium japonicum Houtt., Nat. Hist. II(9) : 282, tab. 56, fig. 1. 1778.

Lectotypus (designated here by Callmander \& Fumeaux): JAPAN: Thunberg s.n. (G-PREL [G00818103]!; isolecto- : UPS-THUNB n 13283 , UPS-THUNB n 13284 images seen).

Notes. - A Thunberg specimen of original material is in the Japan herbarium in G-PREL. It is a good match for the plate and is designated here as the lectotype.

106. Tomex japonica Thunb., Nov. Gen. Pl. 3: 65. 1783.

$\equiv$ Litsea japonica (Thunb.) Juss. in Bull. Soc. Philom. Paris 3: 73.1801.

Typus: JAPAN: Thunberg s.n. (UPS-THUNB $\mathrm{n}^{\circ} 11258$ image seen; G-PREL [G00818147, G00818148, G00818149]!).

Notes. - Three original specimens collected by Thunberg are in G-PREL. Two are in Houttuyn's Japan herbarium [G00818147, G00818148] and one in Burman's [G00818149].
107. Tragia involucrata L., Sp. P1.: 980.1753 [cited in Nat. Hist. II(6): 221. 1776].

Notes. - A specimen without Houttuyn's annotation in the Ceylon herbarium is in G-PREL [G00818085]. It is annotated by Müller Argoviensis as "Tragia involucrata $\delta$ genuina", an invalid name.

108. Trichomanes aethiopicum Burm. f., F1. Ind. (Prodr. F1. Cap.): 32. 1768 .

$\equiv$ Asplenium aethiopicum (Burm. f.) Bech. in Candollea $6: 22.1935$.

Lectotypus (designated here by Callmander \& Fumeaux): South Africa: Cape, Auge s.n. [?] (G-PREL [G00818004]!).

Notes. - Two specimens are present in Houttuyn's Cape herbarium (G-PREL [G00818004, G00818005]) and one in Burman's (G-PREL [G00818089]). The only collection that bears the name Trichomanes aethiopicum is designated here as the lectotype.

109. Truellum japonicum Houtt., Nat. Hist. II(8): Aanwyz. Plaat. [2], 427, fig. 48, tab. 1.1777.

Lectotypus (designated here by Wijnands) : JAPAN : Thunberg s.n. (G-PREL [G00818086]!; isolecto-: UPSTHUNB n 9714 image seen).

= Polygonum senticosum (Meisn.) Franch. \& Sav., Enum. P1. Jap. 1: 401. 1875.

Notes. - The genus Truellum Houtt. is currently considered a synonym of Polygonum L. Original material of Truellum japonicum is present in the Japan herbarium in G-PREL. This collection is a good match for the plate and is designated here as the lectotype. A duplicate is present in UPS-THUNB.

110. Verbena officinalis L., Sp. P1.: 20. 1753.

Notes. - A specimen collected by Thunberg is in the Japan herbarium in G-PREL [G00818087]. Houttuyn annotated it with a reference to Thunberg's "Flora japonica p. 22".

111. Xanthium strumarium L., Sp. P1.: 987.1753 [cited in Nat. Hist. II(9): 241. 1774].

Notes. - A specimen collected by Thunberg is in the Japan herbarium in G-PREL [G00818098]. The collection was determined by Thunberg as Xantbium orientale L. 


\section{Acknowledgements}

Dirk Onno Wijnands initiated this work with the contribution of JH. JFV originally worked on a draft left by Wijnands and enhanced several parts of the article presented here. NF located specimens seen by Wijnands in G-PREL while MWC found several new Houttuyn collections. JFV, NF and MWC finalized the manuscript presented here. The authors wish to thank P. Smit, Professor of Biohistory at Utrecht University, for free access to his unpublished notes on Houttuyn's Natuurlijke Historie, P. Vorster (STEU) for sending xeroxes of the Pelargonium sheets he had on loan, M. Thulin (UPS) for checking Houttuyn's specimens at UPS and K. Bremer (UPS) for the identification of Athanasia tomentosa.J.F. Aleva (WAG) kindly checked some ferns in $\mathrm{G}$ during a visit in December 1986. J.R.J. van Beek (formerly in Utrecht) is acknowledged for his notes on the Houttuyn herbarium made in the spring of 1985, financed by a grant of the Dutch Organization of Pure Scientific Research (ZWO) for his research in Geneva. Study of the Houttuyn herbarium in G by Wijnands in early 1991 was made financially possible by the Conservatoire et Jardin botaniques de la Ville de Genève (CJBG). F. Bouman (AMD) pointed out the presence of Houttuyn material in AMD (now in L). G. Thijsse, Collection Manager in L, provided many additional specimens and advised on the paper used, watermarks, and the 18th century Dutch ornamental pots. For the finalization of the manuscript M. Hecquet (G) kindly provided a CD-ROM to JFV with the scans of a number of specimens present in the Burman herbarium to Wijnands. MWC thanks M. Hjertson (UPS) for his very efficient support in sending scans of UPS-THUNB specimens; F. Rakotondrainibe (P) for her help with Osmunda japonica; P. Riedy (G) for scanning the figures; P. Lowry (MO), A. Stork $(G)$ and P. Perret $(G)$ for their help and support in bringing this manuscript to publication.

\section{Unpublished sources}

ARA: Algemeen Rijksarchief (General State Archives, The Hague).

Candolle, A.P. De (1801). Lettre de Candolle à sa mère [13.I.1801]. Collection privée de Candolle, Genève.

CAndolle, A.P. DE (1830a). Catalogue de l'herbier d'après les époques et les origines des échantillons qui le composent. Collection privée de Candolle, Genève.

GAA: Gemeentearchief Amsterdam (Municipal Archives, Amsterdam) records of the Hortus Botanicus, "Memoriael” PA 27.

\section{References}

Albers, F., J.J.A. van der Walt, M. Gibby, D.E. Marschewitz, R.A. Price \& G. Du Preez (1995). A biosystematic study of Pelargonium section Ligularia: 2. Reappraisal of section Chorisma. S. African J. Bot. 61: 339-346.

Arnold, T. H. \& B.C. DE Wet (ed.) (1993). Plants of southern Africa: names and distribution. Mem. Bot. Surv. South Africa 62.

Arrenberg, R. (1788). Naamregister van de bekendste en meest in gebruik zijnde Nederduitse boeken. Rotterdam.

Backer, C.A. \& R.C. Bakhuizen van Den Brink f. (1965). Fl. Java 2. Groningen.

Bakhuizen van Den Brink, R.C. Jr. (1943). A contribution to the knowledge of the Melastomataceae occurring in the Malay archipelago especially in the Netherlands East Indies. Recueil Trav. Bot. Néerl. 40.

Boeseman, M. \& W. De Ligny (2004). Martinus Houttuyn (17201798) and his contributions to the natural sciences, with emphasis on zoology. Zool. Verh. 349.

Brown, N.E. (1929). The Iridaceae of Burman's Florae capensis prodromus. Bull. Misc. Inform. Kew 1929: 129-137.

Bruijn, J.R., F.S. Gaastra \& E.S. van Eyck van Heslinga (1979). Dutch-Asiatic shipping in the 17 th and 18 th centuries. 3 vol. The Hague.

Burdet, H.M. (1975). Cartulae ad botanicorum graphicem. VII. Candollea $30: 379-410$.

Burdet, H. (2008). Collections de Candolle: catalogue des collecteurs botaniques, une documentation. I: Catalogue. Genève.

Burman, J. (1737). Thesaurus zeylanicus, exhibens plantas in insula Zeylana nascentes. Amsterdam.

Burman, N.L. (1768). Flora Indica: cui accedit series zoophytorum indicorum, nec non prodromus florae capensis. Amsterdam.

Callmander, M.W., O.D. Durbin, H.W. Lack, P. Bungener, P. Martin \& L. Gautier (2017). Etienne-Pierre Ventenat (1757$1808)$ and the gardens of Cels and Empress Joséphine. Candollea $72: 87-132$.

CAndolle, A. DE (1880). La phytographie; ou, L'art de décrire les végétaux considérés sous différents points de vue. Paris.

Candolle, A.P. de (1811). Monographie des Ochnacées et des Simaroubées. Ann. Mus. Natl. Hist. Nat. 17 : 398-425.

Candolle, A.P. DE (ed.) (1830b). Prodromus systematis naturalis regni vegetabilis 4 . Paris.

Candolle, A.P. de (ed.) (1838). Prodromus systematis naturalis regni vegetabilis 6 . Paris.

Candolle, A.P. de (2004). Mémoires et souvenirs (1778-1841), Candaux, J.D. et al. (ed.). Genève.

Christmann, G.F. \& G.W.F. Panzer (1777-1788). Vollständiges Pflanzensystem. 14 vol. Nürnberg. 
Churchill, W.A. (1967). Watermarks in paper in Holland, France, England, etc., in the 17th and 18th centuries and their interconnection. Amsterdam.

Commelin, J. (1701). Horti medici amstelodamensis 2. Amsterdam.

Соок, A. (2016). Laurent Garcin, M.D. F.R.S.: A Forgotten Source for N. L. Burman's Flora indica (1768). Harvard Pap. Bot. 21 : 31-53.

Corner, E.J.H. (1939). Notes on the systematy and distribution of Malayan phanerogams, II. The Jack and the Chempedak. Gard. Bull. Singapore 10 : 56-81.

Dahlgren, R. (1960). Revision of the genus Aspalathus. Part I. The species with flat leaves. Opera Bot. 4.

Dahlgren, R. (1968). Revision of the genus Aspalathus. II (The species with ericoid and pinoid leaflets. 6. The Aspalathus frankenioides, nivea, juniperina, rubens and divaricata groups and some other groups. Opera Bot. 21.

Dancer, T. (1792). Catalogue of plants, exotic and indigenous, in the botanical garden, Jamaica 1. St. Jago de la Vega.

Decaisne, J. (1839). Enumeratio Lardizabalearum. Ann. Sci. Nat., Bot. ser. 2, $12: 99-108$.

De Jong, P.C. (1993). In memoriam Dr. D. Onno Wijnands. Dendroflora 30: 3-4.

De Wilde, W.J.J.O. (2000). Myristicaceae. Fl. Males. I, 14.

Ebihara, A., S. Ekman, M. Hjertson, M. Myrdal \& U. Jinbo (2016). Thunberg's Japanese plants [http://cpthunberg.ebc.uu.se].

FLORIJN, P.J. (1986). Biographical notes about four plant collectors in Asia mentioned by N.L. Burman in his Flora indica (1768). Taxon 36:34-38.

Forman, L.L. (1956). The Menispermaceae of Malaysia. I. Kew Bull. 11: 49-58.

Fuchs, H.P. (1962). Publication dates of Houttuyn's “translation” of Linnaeus's "Systema Naturae”. Taxon $11:$ 41-48.

Goldblatt, P. (1989). The genus Watsonia. A systematic monograph. Ann. Kirstenbosch Bot. Gard. 19.

Goldblatt, P. \& J.C. Manning (1989). Systematics of the southern African genus Ixia L. (Iridaceae) : 5. Synopsis of section Ixia, including five new species. S. African J. Bot. 104: 175-198.

Goldblatt, P., J.C. Manning \& R.E. Gereau (2013). The Cape genus Micranthus (Iridaceae: Crocoideae), nomenclature and taxonomy. Bothalia 43 : 127-144.

Goudswand, P.C. (1980). The genus Zoysia (Gramineae) in Malesia. Blumea 26: 169-175.

Gunn, M. \& L.E. Codd (1981). Botanical exploration of Southern Africa. Cape Town.

Hall, H.C. van (1830). Epistolae ineditae Caroli Linnaei;... et Thunbergii; annis 1763-1793. Groningen.
Hallier, H. (1918). Die botanischen Ergebnisse der Elbert'schen Sunda-Expedition des Frankfurter Vereins fur Geographie und Statistik. III. Meded. Rijk. 37: 1-92.

Harvey, W.H. (1862). Aspalathus Linn. In: Harvey, W.H. \& O.W. Sonder (ed.), Fl. Cap. 2: 94-142.

Heniger, J. (1986). Hendrik Adriaan van Reede tot Drakenstein (16361691) and Hortus Malabaricus. Rotterdam \& Boston.

Hilliard, O.M. \& B.L. Burtt (1981). Names in Gnaphalium, Xeranthemum and Helichrysum published between 1753 and 1800. Bot. J. Linn. Soc. 82: 233-265.

Hochreutiner, B.P.G. (1934). Plantae Hochreutineranae. III. Candollea 5 : $175-341$.

Holtтum, R.E. (1991). Tectaria group. Fl. Males. II, 2(1): 1-132.

Hoogland, R.D. (1953). The genus Tetracera (Dilleniaceae) in the Eastern Old World. Reinwardtia 2: 185-223.

Houttuyn, M. (1761-1785). Natuurlijke Historie of Uitvoerige Beschrijuing der Dieren, Planten en Mineraalen. Parts I-III, 37 vol. Amsterdam.

Houttuyn, M. (1762). Letter from Martinus Houttuyn to Carl Linnaeus. 22.VIII.1762. The Linnaean correspondence, letter L3123 [www.linnaeus.c18.net/Letter/L3123].

Houttuyn, M. (1773-1783a). Natuurlijke Historie of Uitvoerige Beschrijuing der Dieren, Planten en Mineraalen II [Planten]. 14 vol. Amsterdam.

Houttuyn, M. (1773-1783b). Handleiding tot de plant-en kruidkunde. 14 vol. Amsterdam.

Houttuyn, M. (1785). Systematische bladwijzer der planten. Natuurlijke Historie III [Mineraalen]. 5 [not paginated, 164 pages from leaf Cc3]. Amsterdam.

Houttuyn, M. (1789a). Catalogus van eene uitmuntende Verzameling van Plantgewassen .... Amsterdam.

Houttuyn, M. (1789b). Aanmerkingen over de bloemen van den nooten-moskaat-boom. Natuurk. Verh. Maatsch. Wetensch. Haarlem $26: 211-224$.

Hoven Kamp, P.H. (1986). A monograph of the fern genus Pyrrosia. Leiden Bot. Ser. 9.

Hoven kamp, P.H. \& F. Miyamoto (2005). A conspectus of the native and naturalized species of Nephrolepis (Nephrolepidaceae) in the world. Blumea 50:279-322.

IAmonico, D. (2014). Lectotypification of Linnaean names in the genus Achyranthes (Amaranthaceae). Taxon 63: 405-407.

Innma, Y. (1874). Sintei somoku dzusistsu. Ed. 2.20 vol.

Jessop, J.P. (1976). Studies in the bulbous Liliaceae in South Africa 6. The taxonomy of Massonia and allied genera.J. S. African Bot. 42: 401-437.

Juel, H.O. (1918). Plantae thunbergianae. Uppsala \& Leipzig. 
Kanis, A. (1968). A revision of the Ochnaceae of the Indo-Pacific area. Blumea $16: 1-82$.

Kanis, A. (1987). Ochnaceae. In: Dassanayake M.D. \& F.R. FosBERG (ed.), A revised handbook to the Flora of Ceylon 6: 245-254. New Delhi.

Katsuyama, T., N. Tanaka \& W. Ohnishi (2013). The Plant of Hakone recorded in the Thunberg's Flora Japonica. Bull. Kanagawa Prefect. Mus. (Nat. Sci.) 42: 35-62.

Keraudren, M. \& J.B. Gillett (1963). Sur le type du Moringa oleifera Lam., et la valeur de ce binôme. Bull. Soc. Bot. France 110: 316-318.

KnaAp-van Meeuwen, M.S. (1970). A revision of four genera of the tribe Leguminosae-Caesalpinioideae-Cynometreae in Indomalesia and the Pacific. Blumea 18:1-52.

Lasègue, A. (1845). Musée botanique de M. Benjamin Delessert. Paris.

Lewis, G.J. (1962). South African Iridaceae. The genus Ixia. J. S. African Bot. 28: 45-195.

Lewis, G.J. \& A.A. Obermeyer (1972). Gladiolus: A revision of the South African Species. J. S. African Bot., Suppl. 114.

Linnaeus, C. (1766-1768). Systema naturae ed. 12. Stockholm.

Linnaeus, C. (1767). Mantissa plantarum. Stockholm.

Linnaeus, C. (1771). Mantissa plantarum 2. Stockholm.

Linnaeus, C. (1774) [ed. Murray, J.A.]. Systema vegetabilium ed. 13. Göttingen.

Linnaeus f., C. (1782). Supplementum Plantarum. Braunschweig.

Linnaean Plant Name Typification Project (The) (2016). Natural History Museum, London [http ://www.nhm.ac.uk/ our-science/data/linnaean-typification].

Lourteig, A. (1966). L'herbier de Paul Hermann, base du Thesaurus zeylanicus de Johan Burman. Taxon 15: 23-33.

Makino, T. (1907). Observations on the flora of Japan. Bot. Mag. (Tokyo) $21: 56-63$.

McNeill, J.M., F.R. Barrie, W. R. Buck, V. Demoulin, W. Greuter, D.L. Hawksworth, P.S. Herendeen, S. Knapp, K. Marhold, J. Prado, W.F. Prud'Homme van Reine, G.F. Smith, J.H. Wiersema \& N. J. Turland (2012). International Code of Nomenclature for algae, fungi, and plants (Melbourne Code). Regnum Veg. 154.

Meeuse, A.D.L \& W.G. Welman (2000). Convolvulaceae. In: Germishuizen. G. (ed.), Fl. Southern Africa 28(1). Pretoria.

Merrill, E.D. (1938). A critical consideration of Houttuyn's new genera and new species of plants, 1773-1783. J. Arnold Arbor. 19: 291-375.

Merrill, E.D. (1939). Additional notes on Houttuyn's binomials. J. Arnold Arbor. 20: 264-268.
Morren, C. (1843). Notice sur Augustin-Pyrame de Candolle. Annuaire Acad. Roy. Sci. Bruxelles 9: 124-176.

MüLler, P.L.S. (1773-1776). Des Ritters Carl von Linné ... vollständiges Natursystem : nach der zwölften lateinischen Ausgabe und nach Anleitung des holländischen Houttuynischen Werks mit einer ausführlichen Erklärung ausgefertiget von Philipp Ludwig Statius Müller. 6 vol. and supplement. Nürnberg.

Murray, J.A. (1784). Systema vegetabilium ed. 14. Göttingen.

NaKai, T. (1952). A synoptical sketch of Korean flora. Bull. Natl. Sci. Mus. Tokyo 31.

Nordenstam, B. \& M.H. Buys (2011). A reassessment of the supposed Echium homonyms in the Prodromi of Burman and Thunberg with typification of their Echium names now in Lobostemon and Eriostachys. Taxon 60: 1189-1193.

Oнаsнi, H. (2004). Taxonomy and distribution of Desmodium and related genera (Leguminosae) in Malesia (I).J.Jap. Bot. 79: 101-139.

Ohwi, H. (1965) [ed. Meyer, F.G. \& E.H. Walker]. Flora of Japan. Washington DC.

PÉnzes, A. (1936). Rozsnok (Bromus) tanulmányok. Bot. Közlem. $33: 98-138$.

Persoon, C.H. (1805). Synopsis plantarum 1. Paris, Tübingen.

Posthumus, J. \& P. Posthumus (1789), see Houttuyn (1789a).

Rauschert, S. (1970). Das Herbarium von Paul Hermann (16461695) in der Forschungsbibliothek Gotha. Hercynia ser. 2, 7 : 301-328.

Schelpe, E.A.C.L.E. \& N.C. Anthony (1986). Pteridophyta. In : Leistner, O.A. (ed.), Fl. Southern Africa.

SinclAir, J. (1968). Florae malesianae praecursores - XLII. The genus Myristica in Malesia and outside Malesia. Gard. Bull. Singapore 23.

Smith, J.E. (1793). A sketch of a tour on the continent, in the years 1786 and 1787. London.

Stafleu, F.A. \& R.S. Cowan (1979). Taxonomic literature 2 ed. 2. Regnum Veg. 98.

Staples, G.W. \& F. Jaceuemoud (2005). Typification and nomenclature of the Convolvulaceae in N. L. Burman's Flora Indica, with an introduction to the Burman collection at Geneva. Candollea 60 : 445-467.

Stearn, W.T. (1947). The name Lilium japonicum as used by Houttuyn and Thunberg. Lily Yearb. N. Amer. Lily Soc. 1: 101-108.

STrid, A.K. (1972). Revision of the genus Adenandra (Rutaceae). Opera Bot. 32.

Swartz, O. (1788). Nova genera et species plantarum seu Prodromus. Stockholm.

Swartz, O. (1801). Genera et species filicum. J. Bot. (Schrader) 2 : 3-120. 
Tagawa, M. (1957). Pyrrosia of Japan, Korea, and the Ryukyu Islands. J. Jap. Bot. 32: 353-357.

Thunberg, C.P. (1771-1775). Letters from Carl Peter Thunberg to Carl Linnaeus. 4.IV.1771-15.VI.1775. The Linnaean correspondence, letters L4492, L4524, L4588, L4602, L4647, L4659, L4810, L4822, L4835, L4851, L4872, L4900, L4988, L5004, L5007, L065, L5112 [www.linnaeus.c18.net].

Thunberg, C.P. (1776). Beskrifning på et nytt Örte-genus, kalladt Rademachia, hvilket redan utaf Rumphius blifvet afritadt och, fastån ofullkomligen, beskrifvit; men nu efter sexual-methoden noga undersökt. Kongl. Vetensk. Acad. Handl. 37: 250-255.

Thunberg, C.P. (1779). Sitodium incisum et macrocarpon, ususque fructuum qui exinde nascuntur, descripta a Carolo Petro Thunberg, M. D. Philos. Trans. Roy. Soc. London 69: 462-484.

Thunberg, C.P. (1781). Nova genera plantarum 1. Uppsala.

Thunberg, C.P. (1782). Nova genera plantarum 2. Uppsala.

Thunberg, C.P. (1784). Flora japonica. Leipzig.

Thunberg, C.P. (1794a). Prodromus plantarum capensium 1. Uppsala.

Thunberg, C.P. (1794b). Botanical observations on the flora japonica. Trans. Linn. Soc. London 2: 326-342.

Thunberg, C.P. (1794c). Museum naturalium Academiae upsaliensis 16. Uppsala.

Thunberg, C.P. (1796). Voyages de C. P. Thunberg au Japon, par le Cap de Bonne-Espérance, les îsles de la Sonde, Eंc. 4 vol. Paris [French version by L. Langlès and J.B. Lamarck].

Thunberg, C.P. (1800a). Prodromus Plantarum Capensium 2. Uppsala.

Thunberg, C.P. (1800b). Nova genera plantarum 12. Uppsala.

Thunberg, C.P. (1823). Flora capensis ed. 2. Stuttgart.

Thunberg, C.P. (1825). Florula javanica. Uppsala.

Trinius, C.B. von (1820). Fundamenta agrostographiae. Vienna.

Turland, N.J. (2013). The Code decoded. A user's guide to the International Code of Nomenclature for algae, fungi, and plants. Regnum Veg. 155.

VAN DER WALt, J.J.A. \& L. van ZuYL (1988). A taxonomic revision of Pelargonium section Campylia (Geraniaceae). S. African J. Bot. 54: $145-171$.

Van Ooststroom, S.J. (1937). Hermann's collection of Ceylon plants in the Rijksherbarium (National Herbarium) at Leyden. Blumea, Suppl. 1: 193-209.
Van Steenis, C.G.G.J. \& J.F. Veldkamp (1973). Note on Houttuyn's herbarium. Blumea 21:151-152.

Van Steenis-Kruseman, M.J. (1950). Cyclopaedia of collectors. Fl. Males. I, 1.

VAN WYк, B.-E. (1991). A synopsis of the genus Lotononis (Fabaceae: Crotalarieae). Contr. Bolus Herb. 14.

Veldkamp, J.F. (1991). Miscellaneous notes on Southeast Asian Gramineae. VI. Blumea 36: 179-181.

Veldkamp, J.F. (2004). The correct name for Pyrrosia hastata Ching (Polypodiaceae, Pteridophyta). Reinwardtia 12: 191-193.

Ventenat, P.-E. (1803-1808). Choix de plantes, dont la plupart sont cultivées dans le jardin de Cels. Paris.

Vidal, J. (1962). Moringacées. In : Tardieu-Blot, M.L., Fl. Cambodge Laos Vietnam 2: 3-7.

Warburg, O. (1897). Monographie der Myristicaceen. Nova Acta Acad. Caes. Leop.-Carol. German. Nat. Cur. 68.

Wijnands, D.O. (1983). The botany of the Commelins. Rotterdam.

Wijnands, D.O. (1987). The herbarium of M. Houttuyn and its relations to C. P. Thunberg and N. L. Burman. Abstr. XIV Intern. Bot. Congr.: 444. Berlin.

Wijnands, D.O. (1988). Clematis florida en C.P. Thunberg. Dendroflora $24: 3-7$.

Wijnands, D.O. (1990a). The letters of Maarten Houttuyn to Carl Peter Thunberg (1780-1790). Proc. Kon. Ned. Akad. Wetensch. 93 : 77-95.

Wijnands, D.O. (1990b). Correct author citation for species described on material collected by Thunberg in Japan. Thunbergia 12 .

Wijnands, D.O. (1991). Notes on some Monocotyledoneae described by N. L. Burman: Asparagaceae, Asphodelaceae, Colchicaceae. Bothalia $21: 157$.

Wijnands, D.O. (1992). Burman's Prodromus Florae Capensis. Bot. J. Linn. Soc. 109: 485-502.

Wijnands, D.O. \& J. Heniger (1991). The origins of Clifford's herbarium. Bot. J. Linn. Soc. 106: 129-146.

Willdenow, C.L. (1797). Species plantarum 1(1). Berlin.

Willdenow, C.L. (1800). Species plantarum 3(1). Berlin.

Willdenow, C.L. (1803). Species plantarum 3(3). Berlin.

Wood, J.R.I., B.R.M. Williams, T.C. Mitchell, M.A. Carine, D.J. Harris \& R.W. Scotland (2015). A foundation monograph of Convolvulus L. (Convolvulaceae). PhytoKeys 51. 
Appendix I. - The auction catalogue of Houttuyn's herbarium [translated by D.O. Wijnands and J. Heniger].

Houttuyn (1789a, often filed sub Posthumus \& PosthuMus, 1789). Catalogus van eene uitmuntende Verzameling van Plantgerwassen ..., p. 11-14. [Catalogue of an excellent collection of plants...]. There is an annotated copy in the Koninklijke Bibliotheek [Royal Library] in The Hague with the names of the buyers of the zoological objects and the prices obtained, the botanical items unfortunately only have prices, so the travels of these specimens cannot be traced from there.

A. A living Japanese herbarium, collected by the very famous Professor of Upsala Thunberg and like the other one arranged according to the Linnaean Natural System, annotated with the specific names of the plants, with some annotations from the observations of the Medical Dr. M. Houttuyn. NB. This contains about 300 plants, to which are added 70 of which the fructifications need yet to be examined.

B. A living Javanese herbarium, partly collected by the most renowned Prof. Thunberg and likewise very beautifully arranged, annotated with the specific names of the plants and with notes by Dr. M. Houttuyn, as above. NB. The number of the plants in this splendid collection is about 400 to which are added another 125, which need examination.

C. A living Ceylonese herbarium, collected by the same most renowned Prof. Thunberg, and arranged in the same way, annotated with names and notes as above. NB. This contains the number of plants of 165 , to which come 50 less known or to be examined.
D. A living Cape herbarium or collection of Plants gathered from the Cape of Good Hope, carefully examined by Dr. M. Houttuyn with the microscope and arranged according to the Linnaean Natural System, as above, everywhere with annotations and themselves used as the objects of the drawings in the Dutch commentary of the Syst. Nat. NB. The number of the plants of this herbarium is about 250 , which all are distinguished as much as possible with specific names.

E. A living European herbarium, containing plants collected in Spain, Switzerland, and elsewhere, some also indigenous.

F. A medical herbarium, containing for the most plants belonging to Medicine.

G. A Tournefortian herbarium, containing more than two thousand plants beautifully arranged according to the Tournefortian system.

H. A painted Bengal herbarium which is used in medicine, and also noted by the Ceylonese (from the Dutch text: 99 plants from Bengal, to which are added 35 Ceylonese dried plants).

I. Several herbaria.

K. A Book with Cape sea-plants. 
Appendix II. - Index of names treated in the lectotypification and miscellaneous note section, with their current state of use, organised by family.

\section{FERNS}

Aspleniaceae

108. Trichomanes aethiopicum Burm. f. $\equiv$ Asplenium aethiopicum (Burm. f.) Bech.

Davalliaceae

72. Ophioglossum acuminatum Houtt. = Nephrolepis davallioides (Sw.) Kunze

Dryopteridaceae

85. Polypodium japonicum Thunb. ex Houtt. = Cyrtomium falcatum (Thunb. ex L.f.) C. Presl

\section{Gleicheniaceae}

86. Polypodium pedatum Houtt. = Polypodium dichotomum Thunb. = Dicranopteris linearis (Burm. f.) Underw.

\section{Osmundaceae}

75. Osmundajaponica Thunb.

76. Osmunda japonica Houtt. [non O. japonica Thunb.] =Osmunda lancea Thunb.

\section{Polypodiaceae}

2. Acrostichum hastatum Thunb. ex Houtt. $\equiv$ Pyrrosia hastata (Thunb. ex Houtt.) Ching

87. Polypodium trilobum Houtt. = Selliguea triloba (Houtt.) M.G. Price

\section{Pteridaceae}

92. Pteris orbiculata Houtt.

\section{Tectariaceae}

73. Ophioglossum zeilanicum Houtt. $\equiv$ Tectaria zeilanica (Houtt.) Sledge

\section{ANGIOSPERMS}

\section{Acanthaceae}

97. Ruellia ringens sensu Houtt. [non $R$. ringens L.] = Ruellia repens Burm. f. = Hygrophila erecta (Burm. f.) Hochr.

\section{Amaranthaceae}

5. Amaranthus mangostanus sensu Houtt. [non $A$. mangostanus L.] = Amaranthus interruptus $\mathrm{R}$. Br.

26. Celosia japonica Houtt. = Celosia pyramidalis Burm. f. = Celosia argentea $\mathrm{L}$.

54. Illecebrum lanatum (L.) L. $\equiv$ Aerva lanata (L.) Juss. ex Schult.

Amaryllidaceae

6. Amaryllis dubia sensu Houtt. [non $A$. dubia L.] = Nerine sarniensis (L.) Herb.

Anacardiaceae

7. Anacardium occidentale L.

Apiaceae

25. Caucalis japonica Houtt. $\equiv$ Torilis japonica (Houtt.) DC.

27. Chaerophyllum scabrum Thunb. $\equiv$ Torilis scabra (Thunb.) DC.

70. Oenanthe capensis Houtt. = Glia prolifera (Burm. f.) B.L. Burtt

Apocynaceae

13. Apocynum frutescens L. $\equiv$ Ichnocarpus frutescens (L.) W.T. Aiton

66. Nerium oleander L.

67. Nerium zeylanicum L. = Wrightia antidysenterica (L.) R. Br.

Asparagaceae

37. Crinum angustifolium Houtt. = Polianthes tuberosa L.

59. Massonia depressa Houtt.

74. Ornithogalum dubium Houtt.

Asteraceae

14. Arctotis aspera L.

20. Athanasia pubescens sensu Houtt. [non A. pubescens (L.) L.] = Athanasia tomentosa Thunb.

21. Atractylis angustifolia Thunb. ex Houtt. $\equiv$ Berkheya angustifolia (Thunb. ex Houtt.) Merr.

28. Cineraria incisa Thunb. ex Houtt. = Senecio erosus L.f.

44. Erigeron capensis Houtt. $\equiv$ Hilliardiella capensis (Houtt.) H. Rob. et al.

45. Ethulia paniculata Houtt. $=$ Dichrocephala integrifolia $(\mathrm{L}$. f.) Kuntze

50. Gnaphalium aureum Thunb. ex Houtt. $\equiv$ Helichrysum aureum (Thunb. ex Houtt.) Merr.

88. Prenanthes denticulata Houtt. $\equiv$ Crepidiastrum denticulatum (Houtt.) Pak \& Kawano

89. Prenanthes laciniata Houtt. = Lactuca indica $\mathrm{L}$. 
90. Prenanthes lanceolata Houtt. $\equiv$ Crepidiastrum lanceolatum (Houtt.) Nakai

111. Xanthium strumarium L.

Boraginaceae

41. Echium capitatum L. $\equiv$ Lobostemon capitatus (L.) H. Buek

Colchicaceae

9. Anthericum bulbine Houtt. = Wurmbea stricta (Burm. f.) J.C. Manning \& Vinn.

Convolvulaceae

32. Convolvulus batatas L. $\equiv$ Ipomoea batatas (L.) Lam.

33. Convolvulus capensis Burm. f..

34. Convolvulus obscurus L. = Ipomoea obscura (L.) Ker Gawl.

55. Ipomoea pilosa Houtt. = Merremia umbellata (L.) Hallier. f.

Cyperaceae

38. Cyperus javanicus Houtt.

Dilleniaceae

19. Assa indica Houtt. ex Christm. \& Panz. $\equiv$ Tetracera indica (Houtt. ex Christm. \& Panz.) Merr.

39. Dillenia indica L.

Ericaceae

42. Erica pulchella Houtt.

43. Erica splendida Houtt.

Euphorbiaceae

107. Tragia involucrata L.

Fabaceae

1. Abrus precatorius L.

12. Anthyllis ensifolia Houtt. $\equiv$ Psoralea ensifolia (Houtt.) Merr.

16. Aspalathus fascicularis Burm. $\mathrm{f}$.

17. Aspalathus multiflora Thunb. = Aspalathus vermiculata Lam.

18. Aspalathus pedunculata Houtt.

31. Clitoria ternatea L.

52. Hedysarum motorium Houtt. $\equiv$ Codariocalyx motorius (Houtt.) Ohashi

53. Hedysarum vaginale L. $\equiv$ Alysicarpus vaginalis (L.) DC.

58. Lotus capensis Houtt. = Lotononis umbellata (L.) Benth.

83. Poinciana pulcherrima L. $\equiv$ Caesalpinia pulcherrima (L.) Sw.
Geraniaceae

46. Geranium chelidonium Houtt. $\equiv$ Pelargonium chelidonium (Houtt.) DC.

47. Geranium ovale Burm. f. $\equiv$ Pelargonium ovale (Burm. f.) L'Hér.

48. Geranium tetragonum L. f. $\equiv$ Pelargonium tetragonum (L. f.) L'Hér.

Iridaceae

10. Antholyza aletroides Burm. $\mathrm{f} . \equiv$ Watsonia aletroides (Burm. f.) Ker Gawl.

11. Antholyza caryophyllacea Burm. f. $\equiv$ Gladiolus caryophyllaceus (Burm. f.) Poir.

49. Gladiolus liliaceus Houtt.

56. Ixia campanulata Houtt. = Ixia aristata Thunb.

79. Phalangium spicatum Houtt. = Micranthus plantagineus Eckl.

Lamiaceae

29. Clerodendrum infortunatum L.

30. Clerodendrum paniculatum L.

65. Nepeta incana Thunb. ex Houtt. $\equiv$ Caryopteris incana (Thunb. ex Houtt.) Miq.

69. Ocimum sanctum L. = Ocimum tenuiflorum L.

105. Teucrium japonicum Houtt.

Lardizabalaceae

94. Rajania quinata Thunb. $\equiv$ Akebia quinata (Thunb. ex Houtt.) Decne.

Lauraceae

106. Tomex japonica Thunb. $\equiv$ Litsea japonica (Thunb.) Juss.

\section{Liliaceae}

57. Lilium japonicum Thunb. ex Houtt.

Malvaceae

102. Sida cordifolia L.

Melastomataceae

60. Memecylon capitellatum L.,

61. Memecylon floribundum Blume = Memecylon caeruleum Jack

\section{Menispermaceae}

62. Menispermum glabrum sensu Houtt. [non M. glabrum Burm. f.] = Stephania japonica var. discolor (Blume) Forman 
Menyanthaceae

95. Renealmia capensis Houtt. $\equiv$ Villarsia capensis (Houtt.) Merr.

Moraceae

93. Radermachia integra Thunb. $\equiv$ Artocarpus integra (Thunb.) Merr.

\section{Moringaceae}

51. Guilandina moringa L. $\equiv$ Moringa oleifera Lam.

Myristicaceae

64. Myristica fragrans Houtt.

Nyctaginaceae

23. Boerhavia diffusa L.

Ochnaceae

68. Ochna nitida sensu DC. [non O. nitida Sw.] = Ochna jabotapita L.

Oxalidaceae

22. Averrboa carambola L.

77. Oxalis sensitiva L. $\equiv$ Biophytum sensitivum (L.) DC.

Piperaceae

81. Piper officinarum (Miq.) C. DC. = Piper retrofractum Vahl

Plumbaginaceae

82. Plumbago rosea L. = Plumbago indica L.

Poaceae

3. Agrostis javanica Houtt. = Ischaemum muticum L.

4. Aira arundinacea sensu Houtt. [non A. arundinacea L.] = Panicum bisulcatum Thunb.

24. Bromus japonicus Thunb. ex Houtt.

78. Paspalum dissectum (L.) L. $\equiv$ Panicum dissectum L.

80. Phleum indicum Houtt. $\equiv$ Polytrias indica (Houtt.) Veldk.

100. Saccharum japonicum Houtt. $\equiv$ Miscanthus japonicus (Houtt.) Andersson

104. Stipa littorea Burm. f. $\equiv$ Spinifex littoreus (Burm. f.) Merr.

Polygalaceae

84. Polygala japonica Houtt.
Polygonaceae

96. Reynoutria japonica Houtt. $\equiv$ Fallopia japonica (Houtt.) Ronse Decr.

98. Rumex japonicus Houtt.

99. Rumex umbellatus Houtt. = Persicaria chinensis (L.) H. Gross

109. Truellum japonicum Houtt. = Polygonum senticosum (Meisn.) Franch. \& Sav.

Proteaceae

91. Protea linearis Houtt. = Leucadendron brunioides Meisn.

Ranunculaceae

8. Anemone japonica Houtt. $\equiv$ Clematis florida Thunb.

Rosaceae

35. Corchorus japonicus Thunb. ex Houtt. = Kerria japonica (L.) DC.

Rubiaceae

15. Argostemma borragineum Blume ex DC.

36. Crinita capensis Houtt. $\equiv$ Pavetta capensis (Houtt.) Bremek.

63. Mussaenda frondosa $\mathrm{L}$.

71. Oldenlandia linearifolia Thunb.

Rutaceae

40. Diosma pulchella sensu Houtt. [non D. pulchella L.] = Agathosma ovata (Thunb.) Pillans

Scrophulariaceae

101. Selago rapunculoides L. = Selago spuria L.

Smilacaceae

103. Smilax zeylanica L.

Verbenaceae

110. Verbena officinalis L. 